Review

\title{
Quinone and Hydroquinone Metabolites from the Ascidians of the Genus Aplidium
}

\author{
Camila Spereta Bertanha, Ana Helena Januário, Tavane Aparecida Alvarenga, \\ Letícia Pereira Pimenta, Márcio Luis Andrade e Silva, Wilson Roberto Cunha and \\ Patrícia Mendonça Pauletti *
}

Center for Research in Exact and Technological Sciences, University of Franca, Avenue Doutor Armando Salles Oliveira, 201, Franca, São Paulo 14404-600, Brazil;

E-Mails: camila_spereta@hotmail.com (C.S.B.); ana.januario@unifran.edu.br (A.H.J.); farmaciatata@hotmail.com (T.A.A.); leticia_pimenta94@hotmail.com (L.P.P.); marcio.silva@unifran.edu.br (M.L.A.S.); wilson.cunha@unifran.edu.br (W.R.C.)

* Author to whom correspondence should be addressed; E-Mail: patricia.pauletti@unifran.edu.br; Tel.: +55-16-3711-8871; Fax: +55-16-3711-8886.

Received: 1 April 2014; in revised form: 3 June 2014 / Accepted: 4 June 2014 /

Published: 12 June 2014

\begin{abstract}
Ascidians of the genus Aplidium are recognized as an important source of chemical diversity and bioactive natural products. Among the compounds produced by this genus are non-nitrogenous metabolites, mainly prenylated quinones and hydroquinones. This review discusses the isolation, structural elucidation, and biological activities of quinones, hydroquinones, rossinones, longithorones, longithorols, floresolides, scabellones, conicaquinones, aplidinones, thiaplidiaquinones, and conithiaquinones. A compilation of the ${ }^{13} \mathrm{C}$-NMR spectral data of these compounds is also presented.
\end{abstract}

Keywords: ascidian secondary metabolites; structure elucidation; bioactivity; ${ }^{13} \mathrm{C}-\mathrm{NMR}$ spectral data; quinones; hydroquinones

\section{Introduction}

Ascidians or tunicates, are the source of didemnin B, aplidine, and ecteinascidin 743, which have reached clinical trials as antitumor agents. Moreover, aplidine was isolated from Aplidium albicans. Thus, there is a high potential for these organisms to be a novel source of antitumor compounds [1,2]. 
In addition, the compound trabectedin, or ecteinascidin 743 (ET-743, Yondelis ${ }^{\circledR}$, Toronto, Canada), an alkaloid isolated from the ascidian Ecteinascidia turbinate, was the first marine-derived drug to be prescribed against soft tissue carcinoma [3].

The name "tunicate" (sub-phylum Tunicata, Phylum Chordata) was first coined by Lamarck for ascidians, pyrosomes, and salps [4-6]. The name originates from the polysaccharide-containing tunic that envelops the animal and forms a somewhat flexible skeleton [7]. Ascidians (Subphylum Tunicata, Class Ascidiacea), or sea squirts, are the largest and most diverse class of the sub-phylum Tunicata (also known as Urochordata). They comprise approximately 3000 described species, found in all marine habitats, from shallow water to the deep sea [7-9]. Polyclinidae is one of the most diverse families in the class Ascidiacea, within which Aplidium is the most species-rich genus, with 320 known species, based on the species registered in the online World Register of Marine Species [10]. Ascidians, which belong to the family Polyclinidae, genus Aplidium, have been the subject of extensive chemical and biological investigations [11].

The natural products isolated from Aplidium species can be classified into two groups: nitrogenous and non-nitrogenous compounds. Numerous non-nitrogen containing metabolites have been isolated, mainly linear or cyclic prenyl hydroquinones and quinones, which are known as meroterpenes and present cytotoxic activities $[3,11,12]$. Although, there are examples of metabolites that contains nitrogen in the prenylated quinone moiety, such as conicaquinone A, which has an unusual 1,1-dioxo-1,4-thiazine ring added to the quinone moiety. These meroterpenes are the focus of the current review, which describes the structures, biological activities and ${ }^{13} \mathrm{C}-\mathrm{NMR}$ data of 53 prenylated hydroquinones and quinones isolated from Aplidium, thus, highlighting the structural diversity generated in this class of natural products and their potential in drug discovery. A large number of compounds (48) have been examined by ${ }^{13} \mathrm{C}$-NMR spectroscopy so considerable ${ }^{13} \mathrm{C}$ chemical shift data have accumulated; however, a compilation of ${ }^{13} \mathrm{C}$ data for meroterpenes from Aplidium has not been available to date. The assignment of carbon from known compounds is simple and straightforward, providing ${ }^{13} \mathrm{C}$ data of appropriate model compounds are available. Thus, we provide a tabulation of ${ }^{13} \mathrm{C}-\mathrm{NMR}$ data to provide easy access to previously published data on meroterpenes. This paper reports also a brief description of the most characteristics ${ }^{1} \mathrm{H}-\mathrm{NMR}$ chemical shift data.

Prenyl quinones and hydroquinones are metabolites of mixed biogenesis that originate from intra- and inter-molecular cyclizations and/or rearrangements, thus, producing macrocyclic or polycyclic skeletons that are often linked to amino acids or taurine residues [11]. In this report, we have focused on quinones and hydroquinones from Ascidians of the genus Aplidium and their related compounds: rossinones, longithorones, longithorols, floresolides, scabellones, conicaquinones, aplidinones, thiaplidiaquinones, and conithiaquinones. The described compounds were isolated from organisms belonging to 10 identified and three unidentified species of Aplidium. The determination of their structures and biological activities are also summarized, and a compilation of ${ }^{13} \mathrm{C}-\mathrm{NMR}$ spectral data is provided. The intent of the present review is to provide the researchers who have isolated a prenyl quinones and hydroquinones from Aplidium with a quick means of deciding whether the compound is known or new, and to allow them to establish a structure by comparison of ${ }^{13} \mathrm{C}$-NMR data. Additionally, ${ }^{1} \mathrm{H}-\mathrm{NMR}$ spectroscopic studies are often sufficient to establish structures unequivocally; although, there are isomeric molecules that ${ }^{13} \mathrm{C}-\mathrm{NMR}$ data were important to resolve structure 
problems. Aplidium are clearly prolific producers of bioactive prenylated quinones and hydroquinones in the marine environment, and many other Aplidium species need to be investigated.

\subsection{Quinones}

Quinones can be derived by the oxidation of appropriate phenolic compounds, with 1,2-dihydroxybenzenes and 1,4-dihydroxybenzenes, yielding ortho-quinones and para-quinones respectively. Therefore, quinones can be formed from phenolics compounds by either the acetate or shikimate pathways, affording a catechol or quinol system. A range of quinone derivatives and related structures that contain a terpenoid fragment or shikimate-derived portion are also wide spread. For example, ubiquinones (coenzyme Q) have important biochemical functions in electron transport systems for respiration [13]. Figure 1 describes quinones that occur in Aplidium.

Figure 1. Structures of Quinones (1-8).

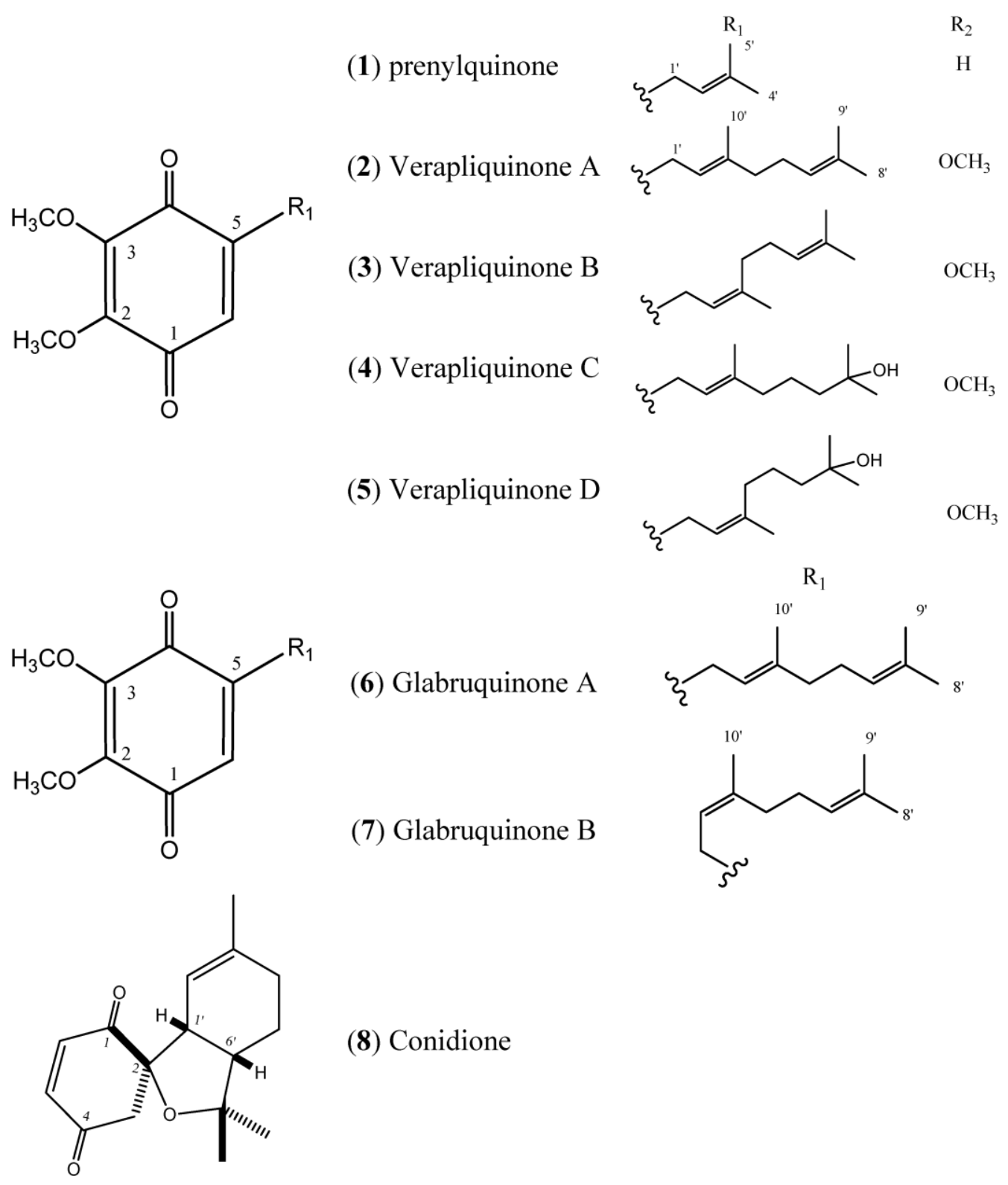


The simple linear Prenylquinone (1) was isolated from Aplidium californicum [14]. The verapliquinones A-D (2-5) were isolated from an unidentified Aplidium sp. (Ascidiacea) collected off the Breton coast. Verapliquinones $\mathrm{A} / \mathrm{B}$ and $\mathrm{C} / \mathrm{D}$ were characterized in a mixture of $E, Z$-isomers by NMR spectroscopy. The NMR data revealed that Verapliquinone B and D had a neryl group at C-2 instead of geranyl [15]. Davis and co-workers [16] reported a simple and versatile route to 1,4-benzoquinones based on the Claisen rearrangement, and applied to the synthesis of verapliquinones A and B, which had not previously been synthesized [16]. Chan and co-workers (2011) also reported verapliquinone A from A. scabellum [17].

Glabruquinone A (6) (or desmethylubiquinone $\mathrm{Q}_{2}$ ) and Glabruquinone B (7) were isolated from Aplidium glabrum and synthesized. The main difference between $\mathbf{6}$ and $\mathbf{7}$ is that compound $\mathbf{6}$ contains a geranyl side chain instead of neryl as in 7 [18]. Glabruquinone A (6) displayed cancer preventive activity in the anchorage-independent transformation assay against mouse JB6 $\mathrm{P}^{+} \mathrm{Cl} 41$ cells transformed with an epidermal growth factor, with an inhibition of the number of colonies $\mathrm{C}_{50}$ $\left(\mathrm{INCC}_{50}\right)$ value of $7.3 \mu \mathrm{M}$. The $\mathrm{INCC}_{50}$ values for 6 were $12.7,17.5$, and $50.5 \mu \mathrm{M}$ against HCT-116, MEL-28, and HT-460 human tumor cells, respectively. Compound 6, at $10 \mu \mathrm{M}$, increased the UVB-induced p53 transcriptional activity of JB6 $\mathrm{P}^{+} \mathrm{Cl} 41$ cells $[18,19]$. Glabruquinone A was also evaluated in vivo on mice inoculated with Ehrlich carcinoma tumors and found to inhibit tumorgrowth. Compound 6 inhibited the phenotype expression of HT-460, HCT-116, and SK-MEL-28 human tumor cells and induced apoptosis of these cell lines, as well as that of HL-60 and THP-1 tumor cells [20].

Conidione (8), a cyclic diprenyl quinone, was isolated from A. conicum but was unstable, and this instability prevented bioassays from being performed [21].

\subsection{Hydroquinones}

Prenylhydroquinone (9), Figure 2, isolated from A. californicum, exhibited activity in vivo against P388 lymphocytic leukemia. The potential cancer protective properties of prenylhydroquinone (9) were also evaluated by employing a modified-Ames assay for mutagenicity against Salmonella typhimurium; when prenylhydroquinone was added to experiments, the mutagenic effects of the carcinogens were drastically reduced [14].

Compound 9 was able to form stable semiquinone radicals according to Cotelle and collaborators, and in presence of glutathione, $\mathbf{9}$ was involved in a redox cycle with the consumption of oxygen. This process triggered the formation of free radicals and decreased the glutathione content, which is considered to be one of the major defenses against oxidative damage. Even although not fully elucidated, the antitumor properties of 9 can be correlated with its redox properties and reactivity toward glutathione [22]. Prenylhydroquinone also inhibits superoxide anion production in rat alveolar macrophages and in the xanthine/xanthine oxidase system. The antioxidant activity of 9 may be attributed to a direct reaction of the superoxide anion rather than to an enzymatic inhibition or a membrane signal transfer [23]. 
Figure 2. Structures of Hydroquinones (9-18).

(9) prenylhydroquinone

(10) geranylhydroquinone

(11) hydroxydiprenylhydroquinone

(12) 2-(3-hydroxy-3,7-dimethyloct-6-<smiles>[R]c1cc(O)ccc1O</smilesenyl)-1,4-benzenediol

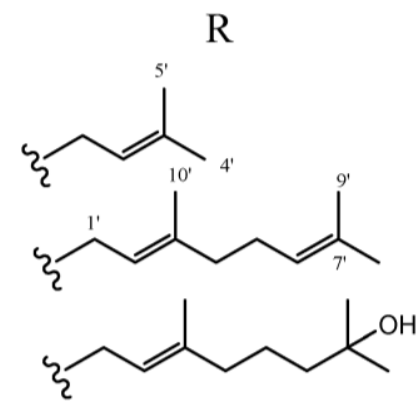

(13) 2-(2Z)-(3-hydroxy-3,7-dimethyloct2,6-dienyl)-1,4-benzenediol<smiles>CC(C)=CCCC(C)(O)CC[12CH3]</smiles>

(14) 2-(1'E)-(3'-hydroxy-3', 7'-

dimethyloct-1',6'-dienyl]-benzene-1,4diol

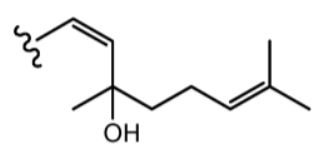

(15) conitriol

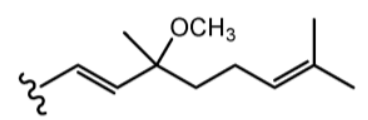

(16) Methoxycononidiol

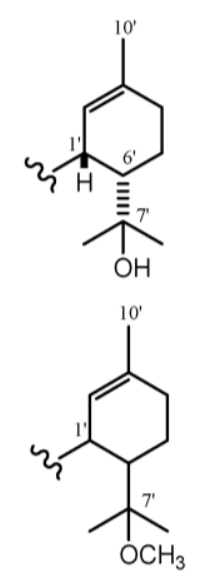<smiles></smiles>

(17) 2-geranyl-6-methoxy-1,4-hydroquinone-4-sulfate<smiles>CC(CCC/C(C)=C/c1cc(O)ccc1O)=C(C)C(=O)C(O)C=C(F)F</smiles>

(18) Rossinone A 
Prenylhydroquinone (9) and geranylhydroquinone (10), isolated from Aplidium sp., have exibited antiproliferative activity ( $\mathrm{IC}_{50}: 41$ and $9.5 \mu \mathrm{M}$, respectively) in a P388 murine leukemia cell-line. Geranylhydroquinone (10) at doses up to $30 \mu \mathrm{M}$ was inactive against the solid tumor cell lines A375 (human melanoma), A549 (human breast), HepG2 (human hepatic), and HT-29 (human colon), as well as normal human liver cells (WRL-68) [24]. Both prenylhydroquinone (9) and geranylhydroquinone (10) exhibited anti-inflammatory activity in an in vitro anti-inflammatory assay with activated human peripheral blood neutrophils by inhibing superoxide production. Compound $\mathbf{1 0}$ was also tested in the DPPH radical scavenging assay, and was considered inactive [24].

Geranylhydroquinone (10) has been reported to occur in various species of Aplidium. It has been isolated from two unidentified Aplidium sp [25,26], A. antillense [27], A. nordmani [28], A. savignyi [29], and A. coninum [21]. Compound $\mathbf{1 0}$ has also been isolated from plants [30-32].

Geranylhydroquinone exhibited cytotoxicity against the leukemia cell lines of Rous sarcoma and mammary cincinoma in vivo [33]. Cytotoxic activity was also observed for $\mathbf{1 0}$ against P-388 leukemia ( $\mathrm{IC}_{50} 0.034 \mu \mathrm{g} / \mathrm{mL}$ ) and $\mathrm{KB}$ human epidermoid carcinoma cells $\left(\mathrm{IC}_{50} 4.3 \mu \mathrm{g} / \mathrm{mL}\right)$. Geranylhydroquinone (10) has also demonstrated antibacterial activity, with a minimum inhibitory concentration (MIC) of $64 \mu \mathrm{g} / \mathrm{mL}$ against Staphylococus aureus and S. faecalis, and an MIC of $128 \mu \mathrm{g} / \mathrm{mL}$ against Serratia marcescens. The minimum bactericide concentrations (MBCs) were determined to be 2,1 , and $>4 \mu \mathrm{g} / \mathrm{mL}$, respectively [27]. Additionally, Compound $\mathbf{1 0}$ was more potent than two standard antioxidants in terms of its inhibitory effects on lipid peroxide formation in rat liver microsomes and on soy-bean 15-lipoxygenase [34].

Geranylhydroquinone (10) and hydroxydiprenylhydroquinone (11) displayed significant cytotoxicity against four tumor cell lines, in particular, against P-388 mouse lymphoma suspension culture ( $\mathrm{IC}_{50} 0.81$ and $4.5 \mu \mathrm{M}$, respectively) indicating that the hydroxylation of the prenyl chain in $\mathbf{1 1}$ may result in a marginal decrease in its cytotoxicity [26].

The compound 2-(3'-hydroxy-3',7'-dimethyloct-6'-enyl)-1,4-benzenediol (12) was isolated from de A. conicum and A. savignyi [14,22]. The compound 2-(2'Z)-(3'-hydroxy-3',7'-dimethyloct-2',6'-dienyl)-1, 4-benzenediol (13) was isolated from A. savignyi [29].

The compounds 2-(1'E)-(3'-hydroxy-3',7'-dimethyloct-1',6'-dienyl]-benzene-1,4-diol (14) and conitriol (15) were isolated from A. conicum but exhibited chemical instability. This instability prevented pharmacological assays from being conducted [21].

Methoxyconidiol (16) was isolated from A. aff. densum [35] and its effects were tested on sea urchin embryos during cell division; compound $\mathbf{1 6}$ disturbed the mitotic spindle assembly leading to a cell cycle arrest during the metaphase/anaphase transition [36]. The antibacterial activity of 16 on Escherichia coli and Micrococcus luteus was also evaluated by microtiter broth dilution method; it had no antibacterial effect [37]. Methoxyconidiol inhibited egg division, with $\mathrm{IC}_{50}$ values of $0.80 \mu \mathrm{M}$ for Paracentrotus lividus eggs and $4.30 \mu \mathrm{M}$ for Sphaerechinus granularis eggs. When tested against the human carcinoma cell lines: MCF7 (breast), PA1 (ovary), PC3 (prostate), CEM-WT (acute lymphoblastic leukemia), and L-929 murine immortalized cells, as well as normal human fibroblasts, 16 was non-toxic to all these cell lines with an $\mathrm{IC}_{50}>100 \mu \mathrm{M}$ [35,37]. Methoxyconidiol caused antimitotic action during the first division of sea urchin embryos, and the mechanism of action of methoxyconidiol may be mediated by the disruption of microtubule dynamics [29]. Hence, Simon-Levert et al. 2010 [37] concluded that methoxyconidiol was ineffective against human cancer 
cells but effective in sea urchin cells. This finding could be explained by a difference between these two type of cells in either membrane permeability and/or intracellular transport of $\mathbf{1 6 .}$

The compound 2-geranyl-6-methoxy-1,4-hydroquinone-4-sulfate (17) was isolated from A. scabellum and inhibited superoxide production by PMA-stimulated human neutrophils in vitro, with an $\mathrm{IC}_{50}$ of $21 \mu \mathrm{M}$. To determine the effect of different treatments on cell survival, drug-treated neutrophils were stained with the fluorescent markers for necrosis (propidium iodide) and apoptosis (Annexin V-FITC), and analyzed by flow cytometry. Treatment with 17 had no effect on neutrophil viability, but the results indicated that $\mathbf{1 7}$ did inhibit neutrophil superoxide production [17].

\subsection{Rossinones}

Rossinones (Figure 3), particularly rossinone B (20) and its derivatives, are linearly fused in a 6,6,5-ring core of rossinone $\mathrm{B}$, which is an extremely rare skeleton, known for only three plant-derived natural products. Rossinone B was isolated for the first time from an unidentified Antarctic species of Aplidium and then from A. fuegiense [24,38]. Therefore, the isolation of $\mathbf{2 0}$ extended the evolutionary range of the requisite biosynthetic terpene cyclase(s) from Plant kingdom to Animalia [24]. To date, five rossinones (18-22) have been discovered.

Figure 3. Structures of Rossinones (19-22).

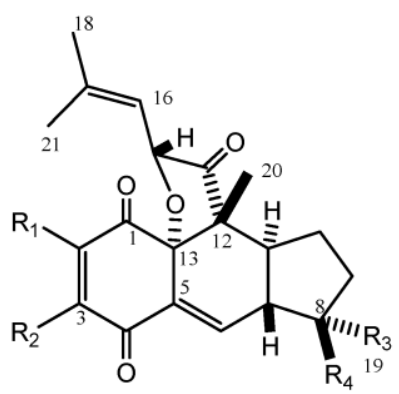

(19) 2,3-Epoxy-rossinone B

$\begin{array}{llll}\mathrm{R}_{1} & \mathrm{R}_{2} & \mathrm{R}_{3} & \mathrm{R}_{4}\end{array}$

(20) Rossinone B

$\mathrm{H}$

$\mathrm{H} \quad \mathrm{OH} \quad \mathrm{CH}_{3}$

(21) 3-Epi-rossinone B<smiles>[Te]O[Te]</smiles>

$\mathrm{OH} \quad \mathrm{CH}_{3}$

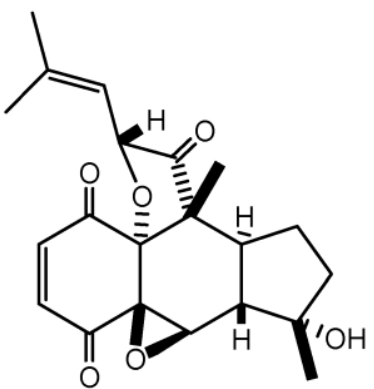

$\mathrm{H}$

$\mathrm{H} \quad \mathrm{CH}_{3} \quad \mathrm{OH}$

(22) 5,6-Epoxy-rossinone B

Rossinones A (18) and B (20) exhibited anti-inflammatory activity in an in vitro anti-inflammatory assay with activated human peripheral blood neutrophils by inhibiting superoxide production. However, in the DPPH radical scavenging assay, $\mathbf{1 8}$ and $\mathbf{2 0}$ were found to be inactive (at doses up to $30 \mu \mathrm{M}$ ), indicating that these rossinones are considerably less effective as superoxide scavengers than as suppressors of superoxide production by neutrophils. Rossinones A and B have exhibited selective antiviral activity against the DNA virus HSV-1, versus the RNA virus PV-1, with both compounds exhibiting antiviral activity at $2 \mu \mathrm{g}$ /disk. Both compounds also exhibited antimicrobial activities against Bacillus subtilis and the fungus Trichophyton mentagrophytes [24]. 
Rossinone B (20) exhibited potent antiproliferative activity toward the P388 murine leukemia cell-line $\left(\mathrm{IC}_{50}: 0.084 \mu \mathrm{M}\right)$, while rossinone A (18) was less active $\left(\mathrm{IC}_{50}: 0.39 \mu \mathrm{M}\right)$. Rossinone A (18) was inactive against the solid tumor cell lines A375 (human melanoma), A549 (human breast), HepG2 (human hepatic), and HT-29 (human colon) at doses up to $30 \mu \mathrm{M}$, while rossinone B (20) presented good activity toward the SH-SY5Y neuroblastoma cell line $\left(\mathrm{IC}_{50}: 1.6 \mu \mathrm{M}\right)$ and modest activity against the A375, A549, and HT-29 cell lines with $\mathrm{IC}_{50}$ values of 11,30 , and $30 \mu \mathrm{M}$, respectively. Additionally, $\mathbf{1 8}$ and $\mathbf{2 0}$ exhibited antiproliferative activity against normal human liver cells (WRL-68) at concentrations up to $30 \mu \mathrm{M}[24]$.

The rossinones 2,3-epoxy-rossinone B, rossinone B, 3-epi-rossinone B, and 5,6-epoxy-rossinone (19-22) isolated from $A$. fuegiense, mainly rossinone $\mathrm{B}$ was proven to be involved in the whole-colony chemical defense of $A$. fuegiense, repelling sea stars and amphipods [39].

\subsection{Longithorones, Longithorols and Floresolides}

Longithorones (Figure 4) and longithorols (Figure 5) are unique farnesylated quinones/hydroquinones isolated from A. longithorax (Monniot). Their complex structures are characterized by the presence of a metacycophane and/or paracyclophane system built in a farnesyl quinone or hydroquinone formally by the rarely encountered cyclization of farnesyl quinones/hydroquinones [12]. One special characteristic of those compounds is the atropisomerism that is caused by the restricted rotations of their macrocyclic rings. Eleven compounds have been isolated (longithorones $\mathrm{A}-\mathrm{K}$ ), including monomeric prenylated quinones (24-26) and dimeric prenylated quinones (23 and 27-31), and the cyclofarnesylated quinones (longithorones $\mathrm{J}$ and $\mathrm{K} ; \mathbf{3 2}-\mathbf{3 3}$ ) [40,41]. The biosynthesis of dimeric longithorones, which have been supposed to originate by both intra- and intermolecular Diels-Alder reactions, has been speculated about. Fusion of the two farnesyl-quinone units can be envisioned as arising via a Diels-Alder cycloaddition of suitably unsaturated precursors, whereas rings $\mathrm{B}$ and $\mathrm{C}$ could arise by a transannular Diels-Alder reaction. The co-isolation of the monomers provides some support for this proposal [12].

Longithorone A (23) displayed cytotoxicity against P388 murine leukemia cells with an $\mathrm{IC}_{50}$ of $\sim 10 \mathrm{mg} \cdot \mathrm{mL}^{-1}$ [42]. In addition, the longithorone $\mathrm{J}(\mathbf{3 2})$ was tested for cytotoxicity against the cell lines SHSY5Y (human neuroblastoma), HEK293T (SV40 T antigen transformed human embryonal kidney cells) and A549 (human non-small cell lung carcinoma). Compound 32 did not exhibit any cytotoxicity in the A549 cell assay when tested at 2 and $20 \mathrm{mg} / \mathrm{mL}$. However, 32 displayed minimal activity at $20 \mathrm{mg} / \mathrm{mL}$ against the SHSY5Y and HEK293T cells, with cell deaths of $28 \%$ and $16 \%$, respectively [43].

Zacarian and collaborators synthesized the highly rigid macrocyclic carbon skeleton of longithorone

C (25) by exploiting quadrupolar interactions as synthetic strategy [44]. Despite the fact that cyclophanes have been extensively synthesized and evaluated because of their unique physical and chemical properties, examples of the isolation and total synthesis of cyclophane-containing natural products are rare and challenging. This has attracted the interest of synthetic chemists in search of new and efficient strategies for syntheses with a reduced number of steps $[45,46]$. 
Figure 4. Structures of Longithorones (23-33).

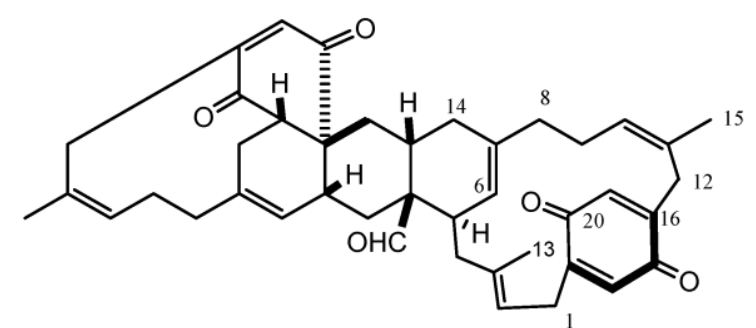

(23) Longithorone A
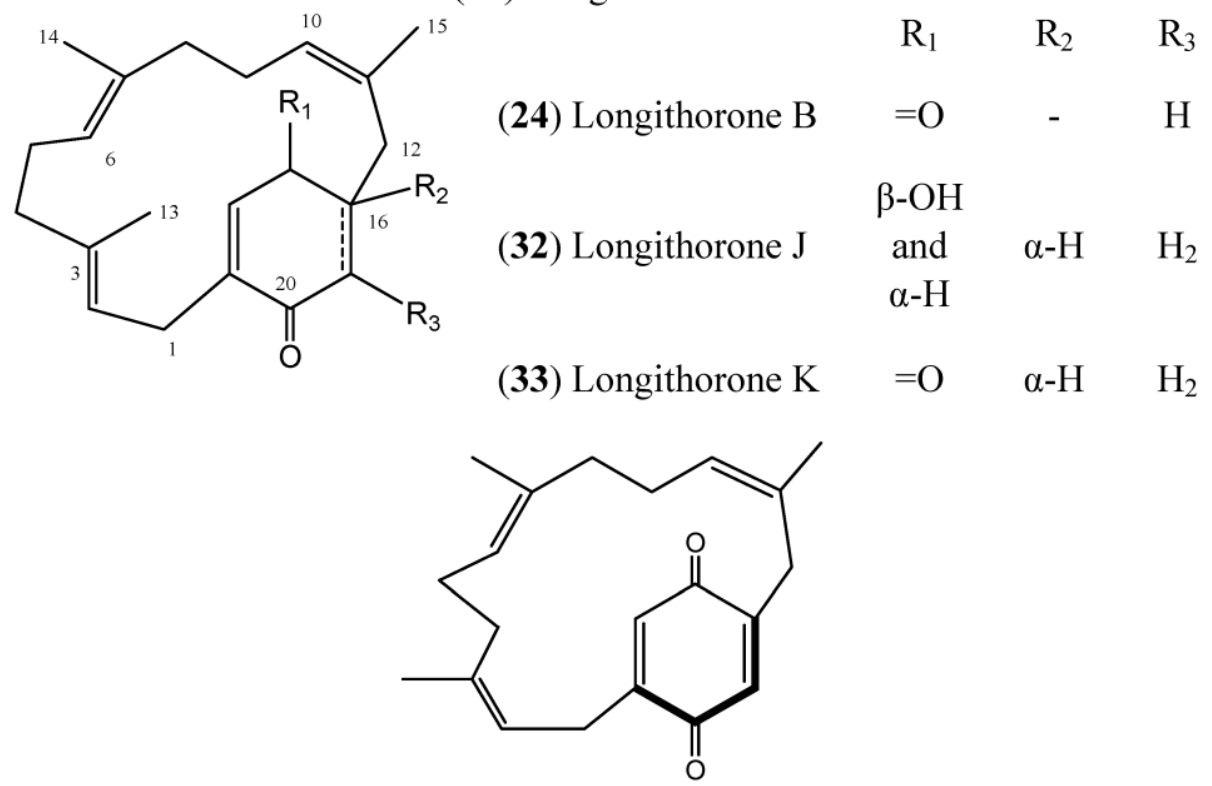

(25) Longithorone C
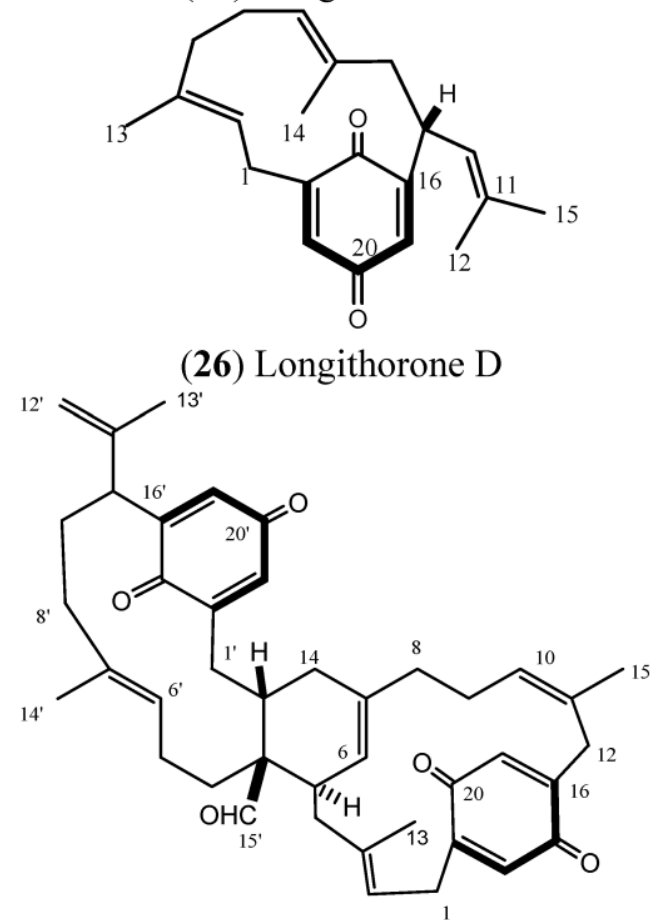

(27) Longithorone E 
Figure 4. Cont.

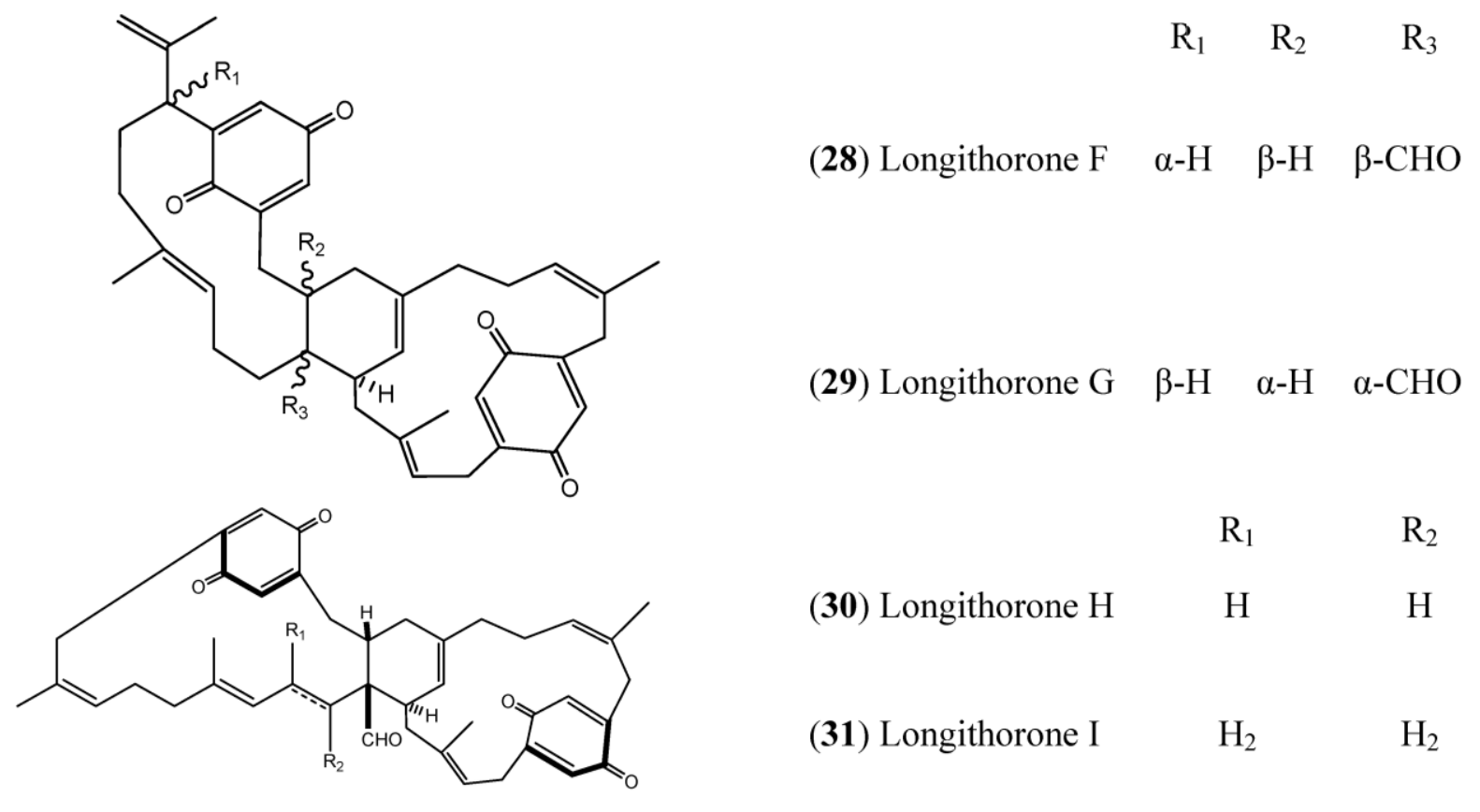

Figure 5. Structures of Longithorol (34-37).

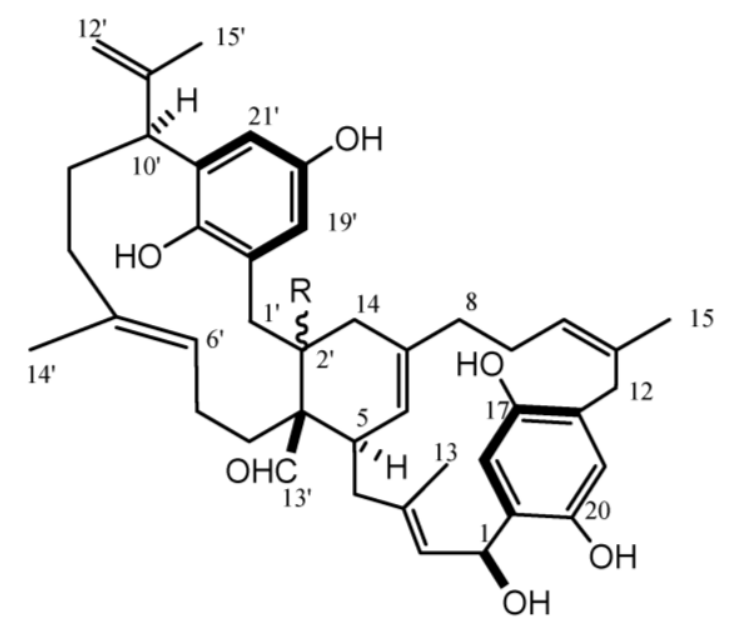

$\mathrm{R}$

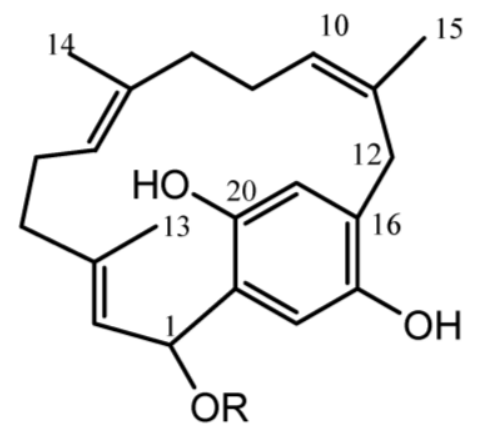

(34) Longithorol A $\alpha-\mathrm{H}$

(35) Longithorol B $\quad \beta-H$

$\mathrm{R}$

(36) Longithorol $\mathrm{C} \quad \mathrm{H}$

(37) Longithorol D $\mathrm{CH}_{3}$

Longithorols A (34) and B (35) are prenylated paracyclophane and metacyclophane hydroquinones, and longithorols $\mathrm{C}$ (36) and D (37) are para-substituted cyclofarnesylated hydroquinones. The hydroquinones (longithorols A-D, 34-37) were also isolated from A. longithorax, moreover 34 and 35 were isolated as their pentaacetate forms because of their instability $[47,48]$. 
Floresolides are monomeric cyclofarnesylated hydroquinones with an endocyclic $\varepsilon$-lactone. They are members of longithorone/longithorol class of meroterpenes. Floresolides A-C (38-40) (Figure 6) have been isolated from Aplidium sp. collected in Indonesian. All of these floresolides exhibited moderate cytotoxicity against KB tumor cells [49]. The synthesis of floresolide B (40) hydroquinone lactone core was performed by employing ring-closing metathesis approach by Briggs and Dudley [50]. The total synthesis of racemic floresolide $\mathrm{B}$ was reported by Nicolaou and $\mathrm{Xu}$, who used an olefin metathesis-based strategy for the formation of the macrocyclic lactone portion [51,52].

Figure 6. Structures of floresolides floresolides (38-40).

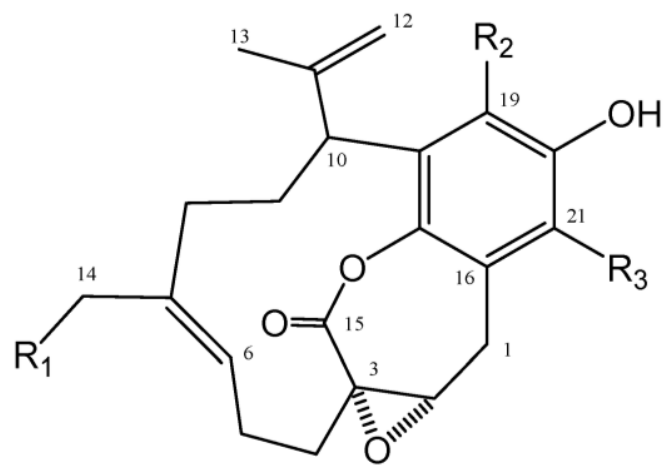

(38) Floresolide $A \quad R_{1}=R_{2}=R_{3}=H$

(39) Floresolide $\mathrm{C} \quad \mathrm{R}_{1}=\mathrm{OH} ; \mathrm{R}_{2}=\mathrm{R}_{3}=\mathrm{Br}$

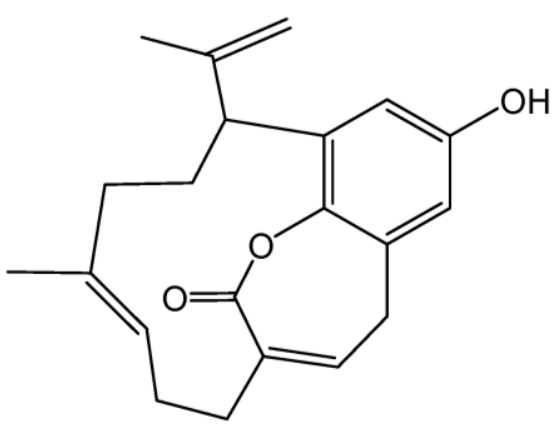

(40) Floresolide B

\subsection{Scabellones}

Chan et al., 2011 [17], have described the isolation of the pseudodimeric meroterpenoid scabellones A-D (41-44) (Figure 7). Scabellone B (42) was able to inhibit the superoxide production by PMA-stimulated human neutrophils in vitro, with an $\mathrm{IC}_{50}$ of $125 \mu \mathrm{M}$. In contrast, $\mathbf{4 2}$ had no effect on neutrophil viability. Scabellone B (42) was also evaluated against the neglected disease parasite targets Trypanosoma brucei rhodesiense, T. cruzi, Leishmania donovani, and Plasmodium falciparum. This compound exhibited selectivity towards only P. falciparum (a K1 chloroquine-resistant strain), with an $\mathrm{IC}_{50}$ of $4.8 \mu \mathrm{M}$, and demonstrated poor cytotoxicity (in a L6 rat myoblast cell line, $\mathrm{IC}_{50}: 65 \mu \mathrm{M}$ ). The core benzo $[c]$ chromene-7,10-dione scaffold of scabellones A-D is rare among natural products and has previously been associated with antiproliferative or apoptosis-inducing biological properties. 
Figure 7. Structures of scabellones (41-44).<smiles>COC1=CC(=O)C(=c2c(=O)cc(OC)c3c4c(c(OC)cc(O)c24)C(F)(F)CC=3)C(=CC=C(C)CCC=C(C)C)C1=O</smiles>

(41) Scabellone A<smiles>COC1=CC(=O)C2=C(C1=O)c1c(cc(OC)c(O)c1CC=C(C)CCC=C(C)C)OC2=CC(C)=CCCC(C)=C(F)F</smiles>

(42) Scabellone B

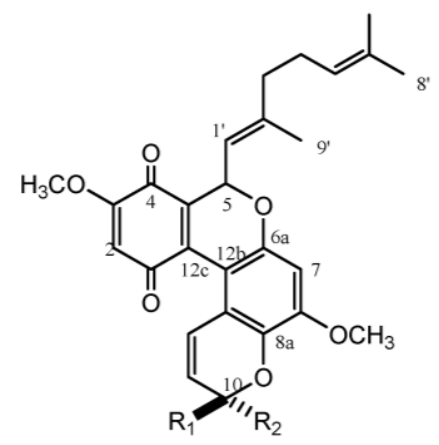

(43) Scabellone C

(44) Scabellone D<smiles>[R]C(C)=CCC</smiles>

\subsection{Conicaquinones, Aplidinones, Thiaplidiaquinones and Conithiaquinones}

Two cytotoxic terpene quinones, the isomeric prenylated quinones conicaquinones $\mathrm{A}$ and $\mathrm{B}(\mathbf{4 5}, \mathbf{4 6})$ (Figure 8), which have an unusual 1,1-dioxo-1,4-thiazine ring added to their quinone moiety, have been isolated from Mediterranean ascidian A. conicum. Both compounds were evaluated in vitro on rat glioma (C6) and rat basophilic leukemia (RBL-2H3) cell lines and demonstrated selectivity against rat glioma cells [53]. A follow-up study with this species, conducted by the same research group resulted in the isolation of three new geranylated quinones, aplidinones A-C (47-49) [54] and two new prenylated benzoquinones, designated as thiaplidiaquinones $\mathrm{A}$ and $\mathrm{B}(\mathbf{5 0}, \mathbf{5 1})$, with an unprecedented tetracyclic skeleton in which a chromenol unit is attached to a $p$-benzoquinone ring condensed to a 1,4-thiazine-dioxide ring. Thiaplidiaquinones A and B were investigated for their antitumor activity. Both compounds were able to induce apoptosis in Jurkat cell lines that were derived from a human $\mathrm{T}$ lymphoma through the overproduction of reactive oxygen species (ROS), which mediated the collapse of the mitochondrial potential $\left(\Delta \Psi_{\mathrm{m}}\right)$. The thiaplidiaquinones 50 and 51 exhibited cytotoxic activity 
against the human leukemia $\mathrm{T}$ cell line Jurkat cells, with an $\mathrm{IC}_{50}$ of approximately $3 \mu \mathrm{M}$ [55]. The total synthesis of thiaplidiaquinone A (50) was described by Carbone [56], while the biomimetic synthesis of thiaplidiaquinone A and B was developed by Copp around the same time [57].

Figure 8. Structures of conicaquinones $(\mathbf{4 5}, \mathbf{4 6})$, aplidinones $(47-49)$, thiaplidiaquinones $(\mathbf{5 0}, \mathbf{5 1})$, and conithiaquinones $(\mathbf{5 2}, \mathbf{5 3})$.<smiles></smiles>

(45) Conicaquinone $\mathrm{A} \quad \mathrm{SO}_{2} \quad \mathrm{NH}$

(46) Conicaquinone B $\mathrm{NH} \quad \mathrm{SO}_{2}$<smiles>[R]c1c(O)cc2c(c1[R])OC(/C=C(/F)CCC=C(F)F)C1=C2C(=O)C2=C(NCCS2(=O)=O)C1=O</smiles>

(47) Aplidinone A

$\mathrm{R}$

(48) Aplidinone B

$\mathrm{OCH}_{3}$

(49) Aplidinone C

$\mathrm{NH}_{2}$

$\mathrm{NHCH}_{2} \mathrm{CH}_{2} \mathrm{SO}_{3}{ }^{-}$

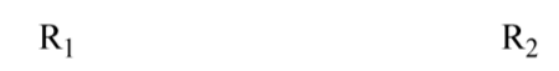

(50) Thiaplidiaquinone A

$\mathrm{H}$<smiles>[Z6]CC=C(C)CCC=C(C)C</smiles>

(51) Thiaplidiaquinone B

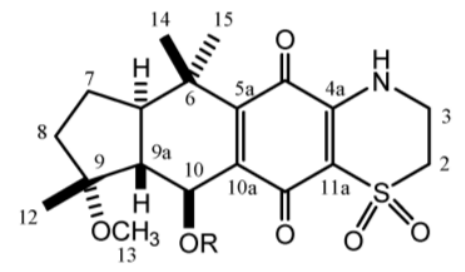

(52) Conithiaquinone A

$\mathrm{H}$

(53) Conithiaquinone B

$\mathrm{CH}_{3}$

Two tetracyclic meroterpenes, conithiaquinones $\mathrm{A}$ and $\mathrm{B}(\mathbf{5 2}, \mathbf{5 3})$, were isolated from $A$. conicum collected off the coast of Sardinia, Italy, and were assayed for their effect on the in vitro growth and viability of human skin keratinocyte (HaCaT line) and human breast adenocarcinoma (MCF-7 line) cells. Conithiaquinone A (52) demonstratedmoderate cytotoxicity against MCF-7 cells with an $\mathrm{IC}_{50}$ value of $44.5 \mu \mathrm{M}[58]$. 


\subsection{Structural Elucidation}

A compilation of the ${ }^{13} \mathrm{C}$ chemical shifts of the quinones (2-4 and 6-8), hydroquinones (9-12 and 14-17), rossinones (18-22), longithorones (23-29 and 32-33), longithorols (34-37), floresolides (38-40), scabellones (41-44), conicaquinones (45-46), aplidinones (47-49), thiaplidiaquinones (50-51), and conithiaquinones (52-53), is given in Tables 1-7. The solvent $\left(\mathrm{A}=\mathrm{CDCl}_{3}, \mathrm{~B}=\mathrm{Me}_{2} \mathrm{CO}-d_{6}, \mathrm{C}=\mathrm{C}_{6} \mathrm{D}_{6}\right.$, $\mathrm{D}=\mathrm{CD}_{3} \mathrm{OD}, \mathrm{E}=\mathrm{CD}_{2} \mathrm{Cl}_{2}$ and $\mathrm{F}=$ DMSO- $\left.d_{6}\right)$ and references are shown in the first line of the tables. Inspection of the ${ }^{13} \mathrm{C}-\mathrm{NMR}$ data of compounds $2-\mathbf{4}$ and 6-8 (prenylated quinones) compared with 9-12 and 14-17 (prenylated hydroquinones) (Tables 1 and 2) reveals the introduction of hydroxyl groups in the C-1 and C-4 in 9-12 and 14-17 (instead of carbonyls group as in 2-4 and 6-8) results in upfield signals at the $\alpha$ carbon. Thus, the quinone family skeleton can be recognized by the typical carbonyl signals.

Table $1 .{ }^{13} \mathrm{C}$ chemical shifts $(\delta$ in ppm) of quinones derivatives. Ref. = References, n.d. $=$ not detected.

\begin{tabular}{ccccccc}
\hline Carbon & $\mathbf{2}$ & $\mathbf{3}$ & $\mathbf{4}$ & $\mathbf{6}$ & $\mathbf{7}$ & $\mathbf{8}$ \\
\hline Solvent & $\mathrm{A}$ & $\mathrm{A}$ & $\mathrm{A}$ & $\mathrm{A}$ & $\mathrm{A}$ & $\mathrm{A}$ \\
\hline Ref. & {$[15]$} & {$[15]$} & {$[15]$} & {$[18]$} & {$[18]$} & {$[21]$} \\
\hline 1 & 182.2 & 182.2 & 187.7 & 184.3 & 184.3 & 197.9 \\
2 & 146.4 & 146.4 & n.d. & 144.9 & 144.9 & 86.9 \\
3 & 132.8 & 132.8 & 132.8 & 145.1 & 145.1 & 50.4 \\
4 & 187.7 & 187.7 & 187.7 & 184.5 & 184.5 & 196.6 \\
5 & 107.1 & 107.1 & 107.1 & 146.9 & 146.9 & 141.1 \\
6 & 158.9 & 158.9 & 158.9 & 130.4 & 130.4 & 140.7 \\
$1^{\prime}$ & 27.1 & 26.9 & 27.2 & 27.1 & 27.2 & 41.8 \\
$2^{\prime}$ & 117.7 & 118.4 & 117.9 & 117.7 & 117.7 & 116.2 \\
$3^{\prime}$ & 140.0 & 140.0 & 139.9 & 140.1 & 140.1 & 139.0 \\
$4^{\prime}$ & 39.6 & 31.8 & 39.9 & 39.7 & 32.0 & 29.2 \\
$5^{\prime}$ & 26.4 & 26.3 & 22.5 & 26.5 & 26.5 & 21.9 \\
$6^{\prime}$ & 123.8 & 123.8 & 43.4 & 123.9 & 123.9 & 46.0 \\
$7^{\prime}$ & 131.8 & 131.8 & 70.9 & 131.9 & 131.9 & 84.7 \\
$8^{\prime}$ & 25.6 & 25.6 & 29.3 & 25.7 & 25.7 & 24.2 \\
$9^{\prime}$ & 17.7 & 16.1 & 29.3 & 17.7 & 17.7 & 23.7 \\
$1^{\prime}$ & 16.1 & 23.5 & 16.0 & 16.2 & 22.7 & 29.0 \\
$\mathrm{OCH}_{3}$ & 56.2 & 56.2 & 56.3 & 61.3 & 61.3 & - \\
$\mathrm{OCH}_{3}$ & - & - & - & 61.2 & 61.2 & - \\
\hline & & & & & &
\end{tabular}

The prenylated quinone family skeleton can also be recognized by the typical ${ }^{1} \mathrm{H}-\mathrm{NMR}$ signals; for example, in the case of compound 2, the doublet of the triplet at $\delta_{\mathrm{H}} 6.43(\mathrm{H}-3, J=2.8$ and $2.2 \mathrm{~Hz})$ and a doublet at $\delta_{\mathrm{H}} 5.86(\mathrm{H}-5, J=2.8)$, and the presence of a methoxyl group at $\delta_{\mathrm{H}} 3.80 \mathrm{~s}$ are typical of the pattern for a 2,6-substituted quinone nucleus [15]. On the other hand, the prenyl hydroquinone core (2-substituted hydroquinone) can be evinced by the typical ${ }^{1} \mathrm{H}-\mathrm{NMR}$ signals for three aromatic hydrogens corresponding to two with an ortho coupling at $\delta_{\mathrm{H}} 6.62(\mathrm{~d}, J=8.5 \mathrm{~Hz})$ and $\delta_{\mathrm{H}} 6.52(\mathrm{dd}$, $J=8.4$ and $2.85 \mathrm{~Hz})$ and one with a meta coupling at $\delta_{\mathrm{H}} 6.55(\mathrm{~d}, J=2.5 \mathrm{~Hz})$, as observed in 10 [29]. 
Table 2. ${ }^{13} \mathrm{C}$ chemical shifts ( $\delta$ in ppm) of hydroquinones derivatives.

\begin{tabular}{ccccccccc}
\hline Carbon & $\mathbf{9}$ & $\mathbf{1 0}$ & $\mathbf{1 1}$ & $\mathbf{1 2}$ & $\mathbf{1 4 a}$ & $\mathbf{1 5}$ & $\mathbf{1 6}$ & $\mathbf{1 7}$ \\
\hline Solvent & $\mathrm{B}$ & $\mathrm{A}$ & $\mathrm{A}$ & $\mathrm{A}$ & $\mathrm{C}$ & $\mathrm{C}$ & $\mathrm{A}$ & $\mathrm{D}$ \\
\hline Ref. & {$[14]$} & {$[29]$} & {$[25]$} & {$[29]$} & {$[21]$} & {$[21]$} & {$[35]$} & {$[17]$} \\
\hline 1 & 148.3 & 148.6 & 147.8 & 147.9 & 147.3 & 148.6 & 149.4 & 141.2 \\
2 & 129.3 & 147.7 & 138.2 & 123.8 & 135.9 & 130.8 & 130.5 & 129.2 \\
3 & 116.9 & 116.6 & 121.8 & 116.6 & 113.2 & 118.7 & 118.8 & 114.1 \\
4 & 150.8 & 148.2 & 149.7 & 148.9 & 150.3 & 148.8 & 148.4 & 146.4 \\
5 & 113.5 & 114.3 & 116.5 & 113.8 & 115.2 & 114.2 & 114.3 & 103.6 \\
6 & 116.1 & 116.2 & 116.4 & 116.9 & 116.8 & 118.4 & 118.2 & 148.6 \\
$1^{\prime}$ & 28.9 & 30.0 & 29.0 & 41.4 & 125.2 & 34.3 & 34.4 & 29.1 \\
$2^{\prime}$ & 123.6 & 120.8 & 113.6 & 24.5 & 124.5 & 125.4 & 125.6 & 123.9 \\
$3^{\prime}$ & 132.1 & 128.1 & 128.1 & 73.8 & 77.6 & 133.7 & 133.8 & 136.7 \\
$4^{\prime}$ & 17.5 & 40.0 & 42.9 & 41.7 & 40.6 & 31.5 & 31.8 & 41.0 \\
$5^{\prime}$ & - & 26.7 & 22.4 & 22.9 & 23.0 & 20.7 & 20.6 & 27.9 \\
$6^{\prime}$ & - & 123.6 & 39.7 & 124.0 & $n . d$. & 49.1 & 47.4 & 125.5 \\
$7^{\prime}$ & - & 122.0 & 71.4 & 132.4 & 131.1 & 75.3 & 79.5 & 132.2 \\
$8^{\prime}$ & - & 26.6 & 29.2 & 25.7 & 25.8 & 32.5 & 25.7 & 25.9 \\
$9^{\prime}$ & - & 18.1 & 29.2 & 17.7 & 22.1 & 23.3 & 19.1 & 17.8 \\
$10^{\prime}$ & - & 15.5 & 16.2 & 26.6 & 17.7 & 22.9 & 23.3 & 16.3 \\
$\mathrm{OCH}_{3}$ & - & - & - & - & 49.9 & - & 49.1 & 56.6 \\
\hline
\end{tabular}

Table 3. ${ }^{13} \mathrm{C}$ chemical shifts ( $\delta$ in ppm) of rossinones derivatives.

\begin{tabular}{ccccccc}
\hline Carbon & $\mathbf{1 8}$ & Carbon & $\mathbf{1 9}$ & $\mathbf{2 0}$ & $\mathbf{2 1}$ & $\mathbf{2 2}$ \\
\hline Solvent & $\mathrm{A}$ & Solvent & $\mathrm{A}$ & $\mathrm{A}$ & $\mathrm{A}$ & $\mathrm{A}$ \\
\hline Ref. & {$[24]$} & Ref. & {$[38]$} & {$[38]$} & {$[38]$} & {$[38]$} \\
\hline 1 & 147.4 & 1 & n.d. & 190.3 & 189.9 & 191.0 \\
2 & 128.1 & 2 & 55.5 & 139.0 & 139.0 & 140.0 \\
3 & 116.3 & 3 & 56.4 & 141.2 & 141.4 & 141.7 \\
4 & 149.7 & 4 & 191.8 & 185.0 & 184.4 & 193.9 \\
5 & 113.9 & 5 & 134.3 & 134.6 & 133.3 & 55.9 \\
6 & 116.2 & 6 & 145.0 & 144.2 & 144.0 & 61.4 \\
$1^{\prime}$ & 28.7 & 7 & 49.7 & 50.5 & 50.5 & 48.5 \\
$2^{\prime}$ & 123.5 & 8 & 78.0 & 78.0 & 78.3 & 79.3 \\
$3^{\prime}$ & 135.5 & 9 & 40.2 & 40.2 & 40.5 & 39.8 \\
$4^{\prime}$ & 38.1 & 10 & 21.0 & 21.1 & 20.9 & 21.1 \\
$5^{\prime}$ & 26.8 & 11 & 39.3 & 39.5 & 39.5 & 34.4 \\
$6^{\prime}$ & 145.2 & 12 & 49.2 & 49.3 & 48.9 & 49.8 \\
$7^{\prime}$ & 134.0 & 13 & 83.8 & 82.8 & 82.8 & 83.7 \\
$8^{\prime}$ & 201.8 & 14 & 212.2 & 213.0 & 212.3 & 212.2 \\
$9^{\prime}$ & 69.8 & 15 & 77.4 & 77.2 & 77.4 & 77.0 \\
$1^{\prime}$ & 122.9 & 16 & 118.7 & 118.6 & 117.8 & 118.5 \\
$11^{\prime}$ & 138.6 & 17 & 142.3 & 142.5 & 143.0 & 142.7 \\
$12^{\prime}$ & 25.8 & 18 & 25.9 & 25.9 & 25.6 & 25.9 \\
$13^{\prime}$ & 15.8 & 19 & 27.1 & 27.1 & 26.7 & 27.4 \\
$1^{\prime}$ & 11.8 & 20 & 8.7 & 8.8 & 8.6 & 11.0 \\
$15^{\prime}$ & 18.3 & 21 & 18.9 & 18.7 & 18.6 & 18.7 \\
\hline
\end{tabular}


Table 4. ${ }^{13} \mathrm{C}$ chemical shifts of ( $\delta$ in ppm) longithorones derivatives.

\begin{tabular}{|c|c|c|c|c|c|c|c|c|c|}
\hline Carbon & 23 & 24 & 25 & 26 & 27 & 28 & 29 & 32 & 33 \\
\hline Solvent & $\mathrm{C}$ & $\mathrm{C}$ & $\mathrm{C}$ & $\mathrm{C}$ & $\mathrm{C}$ & A & $\mathrm{C}$ & A & A \\
\hline Ref. & {$[40]$} & [40] & [40] & {$[40]$} & {$[40]$} & [40] & [40] & [41] & [41] \\
\hline 1 & 27.6 & 29.1 & 28.7 & 29.5 & 27.8 & 29.2 & 29.0 & 28.2 & 28.3 \\
\hline 2 & 125.3 & 122.1 & 120.9 & 121.7 & 125.9 & 123.9 & 122.9 & 122.3 & 120.5 \\
\hline 3 & 136.3 & 138.5 & 139.1 & 139.6 & 135.8 & 136.9 & 136.0 & 135.3 & 137.6 \\
\hline 4 & 40.5 & 39.0 & 27.9 & 39.7 & 40.1 & 39.0 & 42.5 & 39.5 & 39.4 \\
\hline 5 & 36.3 & 24.1 & 24.1 & 25.4 & 37.4 & 36.8 & 37.3 & 23.9 & 23.9 \\
\hline 6 & 119.7 & 122.6 & 123.2 & 131.5 & 120.4 & 121.8 & 122.0 & 123.9 & 123.0 \\
\hline 7 & 134.7 & 135.2 & 135.2 & 131.4 & 134.4 & 138.1 & 137.6 & 134.9 & 135.3 \\
\hline 8 & 37.4 & 39.5 & 39.7 & 44.1 & 37.8 & 36.1 & 35.0 & 39.8 & 39.6 \\
\hline 9 & 26.6 & 29.2 & 30.3 & 43.5 & 26.5 & 26.0 & 27.4 & 29.0 & 28.6 \\
\hline 10 & 126.6 & 127.4 & 126.7 & 126.6 & 126.6 & 127.2 & 126.4 & 128.2 & 128.8 \\
\hline 11 & 132.5 & 130.9 & 132.1 & 132.6 & 132.3 & 130.9 & 131.7 & 133.8 & 130.5 \\
\hline 12 & 35.6 & 32.1 & 32.9 & 17.7 & 35.4 & 31.7 & 33.1 & 29.0 & 36.9 \\
\hline 13 & 15.3 & 14.6 & 22.2 & 15.4 & 15.1 & 15.4 & 15.2 & 14.9 & 14.8 \\
\hline 14 & 32.9 & 15.6 & 16.0 & 14.2 & 37.3 & 37.4 & 37.8 & 16.1 & 16.2 \\
\hline 15 & 27.6 & 26.5 & 27.2 & 25.9 & 27.5 & 26.2 & 27.1 & 22.8 & 22.5 \\
\hline 16 & 149.4 & 148.3 & 149.0 & 151.7 & 149.5 & 146.9 & 148.3 & 38.0 & 46.5 \\
\hline 17 & 187.2 & 187.8 & 187.2 & 187.6 & 186.4 & 187.4 & 187.9 & 71.5 & 200.7 \\
\hline 18 & 131.5 & 130.2 & 132.9 & 149.3 & 131.5 & 129.5 & 129.8 & 147.1 & 136.4 \\
\hline 19 & 148.1 & 147.8 & 149.4 & 129.6 & 147.8 & 148.0 & 148.1 & 138.4 & 151.7 \\
\hline 20 & 187.0 & 188.1 & 187.4 & 188.8 & 187.0 & 188.1 & 187.0 & 196.8 & 197.1 \\
\hline 21 & 133.6 & 132.4 & 133.1 & 133.1 & 133.5 & 132.5 & 132.5 & 42.0 & 42.0 \\
\hline $1^{\prime}$ & 37.8 & - & - & - & 29.5 & 28.3 & 28.7 & - & - \\
\hline $2^{\prime}$ & 30.7 & - & - & - & 39.2 & 44.7 & 39.1 & - & - \\
\hline $3^{\prime}$ & 49.4 & - & - & - & 52.8 & 52.5 & 53.7 & - & - \\
\hline $4^{\prime}$ & 27.6 & - & - & - & 30.9 & 30.1 & 33.1 & - & - \\
\hline $5^{\prime}$ & 38.1 & - & - & - & 21.1 & 19.7 & 22.4 & - & - \\
\hline $6^{\prime}$ & 126.1 & - & - & - & 130.4 & 129.2 & 130.6 & - & - \\
\hline $7^{\prime}$ & 143.8 & - & - & - & 135.4 & 135.1 & 134.6 & - & - \\
\hline $8^{\prime}$ & 34.3 & - & - & - & 40.5 & 39.9 & 39.8 & - & - \\
\hline $9^{\prime}$ & 29.9 & - & - & - & 32.2 & 32.1 & 31.4 & - & - \\
\hline $10^{\prime}$ & 130.4 & - & - & - & 43.4 & 43.2 & 43.3 & - & - \\
\hline $11^{\prime}$ & 132.2 & - & - & - & 147.3 & 147.8 & 147.0 & - & - \\
\hline $12^{\prime}$ & 34.5 & - & - & - & 111.1 & 110.9 & 111.3 & - & - \\
\hline $13^{\prime}$ & 205.5 & - & - & - & 21.4 & 206.3 & 203.8 & - & - \\
\hline $14^{\prime}$ & 30.9 & - & - & - & 15.4 & 15.7 & 14.8 & - & - \\
\hline $15^{\prime}$ & 27.5 & - & - & - & 204.6 & 21.4 & 21.2 & - & - \\
\hline $16^{\prime}$ & 155.7 & - & - & - & 151.2 & 151.5 & 151.8 & - & - \\
\hline $17^{\prime}$ & 200.7 & - & - & - & 187.0 & 186.1 & 187.4 & - & - \\
\hline $18^{\prime}$ & 56.3 & - & - & - & 151.9 & 152.2 & 152.5 & - & - \\
\hline $19^{\prime}$ & 52.9 & - & - & - & 134.0 & 133.8 & 131.8 & - & - \\
\hline $20^{\prime}$ & 201.2 & - & - & - & 187.1 & 188.5 & 187.6 & - & - \\
\hline $21^{\prime}$ & 139.2 & - & - & - & 130.4 & 129.9 & 130.9 & - & - \\
\hline $1-\mathrm{OCH}_{3}$ & & - & - & - & - & - & - & - & - \\
\hline
\end{tabular}


Table 5. ${ }^{13} \mathrm{C}$ chemical shifts of ( $\delta$ in ppm) longithorols and floresolides derivatives.

\begin{tabular}{|c|c|c|c|c|c|c|c|}
\hline Carbon & 34 & 35 & 36 & 37 & 38 & 39 & 40 \\
\hline Solvent & $\mathrm{E}$ & E & $\mathrm{F}$ & $\mathrm{F}$ & A & A & A \\
\hline Ref. & [47] & [47] & [48] & [48] & [49] & [49] & [49] \\
\hline 1 & 67.1 & 67.2 & 71.6 & 81.2 & 33.9 & 34.0 & 30.1 \\
\hline 2 & 129.0 & 129.6 & 130.0 & 127.4 & 63.7 & 62.5 & 137.8 \\
\hline 3 & 135.5 & 135.1 & 131.4 & 133.9 & 59.1 & 58.3 & 136.1 \\
\hline 4 & 39.9 & 40.4 & 38.5 & 38.5 & 33.4 & 32.6 & 31.4 \\
\hline 5 & 37.4 & 38.4 & 23.9 & 23.8 & 24.0 & 23.2 & 25.0 \\
\hline 6 & 119.2 & 119.6 & 120.8 & 121.0 & 123.4 & 126.7 & 124.6 \\
\hline 7 & 137.6 & 137.2 & 134.1 & 134.2 & 137.4 & 141.2 & 135.8 \\
\hline 8 & 36.7 & 37.3 & 38.9 & 38.8 & 39.3 & 35.4 & 37.4 \\
\hline 9 & 24.6 & 24.7 & 25.4 & 26.0 & 29.6 & 25.0 & 29.3 \\
\hline 10 & 126.6 & 126.5 & 125.7 & 125.8 & 43.2 & 44.4 & 41.5 \\
\hline 11 & 131.5 & 131.4 & 133.1 & 133.0 & 149.3 & 143.9 & 149.2 \\
\hline 12 & 36.8 & 36.8 & 33.2 & 32.9 & 109.4 & 111.8 & 108.9 \\
\hline 13 & 16.3 & 16.2 & 15.3 & 15.1 & 21.9 & 22.5 & 22.4 \\
\hline 14 & 39.1 & 37.8 & 16.4 & 16.1 & 14.9 & 58.3 & 13.6 \\
\hline 15 & 27.5 & 27.5 & 27.4 & 27.3 & 169.1 & 167.8 & 166.6 \\
\hline 16 & 133.7 & 133.7 & 125.7 & 126.3 & 137.3 & 128.8 & 135.7 \\
\hline 17 & 148.0 & 148.0 & 147.4 & 147.1 & 142.7 & 142.9 & 144.2 \\
\hline 18 & 120.9 & 120.8 & 112.4 & 114.3 & 128.9 & 133.7 & 132.7 \\
\hline 19 & 132.8 & 132.7 & 127.5 & 124.8 & 114.0 & 112.2 & 112.6 \\
\hline 20 & 143.6 & 143.6 & 147.4 & 147.4 & 153.0 & 150.1 & 152.6 \\
\hline 21 & 126.3 & 126.2 & 117.1 & 117.2 & 114.2 & 109.5 & 112.1 \\
\hline $1^{\prime}$ & 31.6 & 32.6 & - & - & - & - & - \\
\hline $2^{\prime}$ & 44.4 & 39.4 & - & - & - & - & - \\
\hline $3^{\prime}$ & 53.1 & 52.9 & - & - & - & - & - \\
\hline $4^{\prime}$ & 25.8 & 30.6 & - & - & - & - & - \\
\hline $5^{\prime}$ & 19.9 & 20.9 & - & - & - & - & - \\
\hline $6^{\prime}$ & 126.0 & 126.4 & - & - & - & - & - \\
\hline $7^{\prime}$ & 133.9 & 133.9 & - & - & - & - & - \\
\hline $8^{\prime}$ & 40.7 & 40.6 & - & - & - & - & - \\
\hline $9^{\prime}$ & 31.1 & 31.3 & - & - & - & - & - \\
\hline $10^{\prime}$ & 45.6 & 45.8 & - & - & - & - & - \\
\hline $11^{\prime}$ & 149.5 & 149.3 & - & - & - & - & - \\
\hline $12^{\prime}$ & 109.8 & 110.0 & - & - & - & - & - \\
\hline $13^{\prime}$ & 208.7 & 205.9 & - & - & - & - & - \\
\hline $14^{\prime}$ & 15.4 & 15.2 & - & - & - & - & - \\
\hline $15^{\prime}$ & 22.4 & 22.5 & - & - & - & - & - \\
\hline $16^{\prime}$ & 138.4 & 138.1 & - & - & - & - & - \\
\hline $17^{\prime}$ & 143.0 & 142.8 & - & - & - & - & - \\
\hline $18^{\prime}$ & 136.6 & 136.1 & - & - & - & - & - \\
\hline $19^{\prime}$ & 120.8 & 120.8 & - & - & - & - & - \\
\hline $20^{\prime}$ & 148.7 & 148.9 & - & - & - & - & - \\
\hline $21^{\prime}$ & 119.4 & 119.4 & - & - & - & - & - \\
\hline $1-\mathrm{OCH}_{3}$ & - & - & - & 55.4 & - & - & - \\
\hline
\end{tabular}


Table 6. ${ }^{13} \mathrm{C}$ chemical shifts $(\delta$ in ppm) of scabellone derivatives.

\begin{tabular}{ccccccc}
\hline Carbon & $\mathbf{4 1}$ & Carbon & $\mathbf{4 2}$ & Carbon & $\mathbf{4 3}$ & $\mathbf{4 4}$ \\
\hline Solvent & $\mathrm{A}$ & Solvent & $\mathrm{A}$ & Solvent & $\mathrm{A}$ & $\mathrm{A}$ \\
\hline Ref. & {$[17]$} & Ref. & {$[17]$} & Ref. & {$[17]$} & {$[17]$} \\
\hline 1 & 186.4 & 1 & 182.6 & 1 & 185.4 & 184.9 \\
2 & 107.6 & 2 & 107.3 & 2 & 107.1 & 107.2 \\
3 & 158.3 & 3 & 157.8 & 3 & 158.3 & 158.0 \\
4 & 181.5 & 4 & 178.7 & 4 & 179.0 & 178.7 \\
5 & 145.7 & $4 \mathrm{a}$ & 130.8 & $4 \mathrm{a}$ & 131.4 & 131.1 \\
6 & 138.4 & 5 & 67.6 & 5 & 67.7 & 67.7 \\
7 & 109.1 & $6 \mathrm{a}$ & 151.4 & $6 \mathrm{a}$ & 151.6 & 151.3 \\
8 & 145.7 & 7 & 98.4 & 7 & 101.2 & 101.0 \\
9 & 101.4 & 8 & 150.0 & 8 & 153.0 & 152.5 \\
10 & 149.4 & 9 & 139.2 & $8 \mathrm{a}$ & 138.3 & 137.9 \\
$10 \mathrm{a}$ & 136.2 & 10 & 126.8 & 10 & 77.8 & 77.4 \\
12 & 77.5 & $10 \mathrm{a}$ & 111.0 & 11 & 126.6 & 127.4 \\
13 & 131.3 & $10 \mathrm{~b}$ & 137.6 & 12 & 123.8 & 123.6 \\
14 & 120.1 & $1^{\prime}$ & 116.9 & $12 \mathrm{a}$ & 120.2 & 120.5 \\
$14 \mathrm{a}$ & 120.4 & $2^{\prime}$ & 144.3 & $12 \mathrm{~b}$ & 107.6 & 107.1 \\
15 & 25.4 & $3^{\prime}$ & 39.7 & $12 \mathrm{c}$ & 133.9 & 133.6 \\
$1^{\prime}$ & 26.6 & $4^{\prime}$ & 26.3 & 13 & 24.5 & 25.9 \\
$2^{\prime}$ & 118.0 & $5^{\prime}$ & 123.6 & $1^{\prime}$ & 117.0 & 117.0 \\
$3^{\prime}$ & 138.1 & $6^{\prime}$ & 131.7 & $2^{\prime}$ & 144.3 & 144.0 \\
$4^{\prime}$ & 39.2 & $7^{\prime}$ & 17.6 & $3^{\prime}$ & 39.7 & 39.4 \\
$5^{\prime}$ & 26.3 & $8^{\prime}$ & 25.6 & $4^{\prime}$ & 26.2 & 26.1 \\
$6^{\prime}$ & 124.1 & $9^{\prime}$ & 17.2 & $5^{\prime}$ & 123.6 & 123.7 \\
$7^{\prime}$ & 131.2 & $1^{\prime \prime}$ & 26.5 & $6^{\prime}$ & 131.7 & 131.5 \\
$8^{\prime}$ & 17.3 & $2^{\prime \prime}$ & 124.2 & $7^{\prime}$ & 17.7 & 17.6 \\
$9^{\prime}$ & 25.4 & $3^{\prime \prime}$ & 137.1 & $8^{\prime}$ & 25.6 & 25.8 \\
$100^{\prime}$ & 15.6 & $4^{\prime \prime}$ & 39.8 & $9^{\prime}$ & 17.2 & 17.2 \\
$1^{\prime \prime}$ & 39.6 & $5^{\prime \prime}$ & 26.2 & $1^{\prime \prime}$ & 41.1 & 38.5 \\
$2^{\prime \prime}$ & 22.2 & $6^{\prime \prime}$ & 123.8 & $2^{\prime \prime}$ & 23.2 & 22.4 \\
$3^{\prime \prime}$ & 124.0 & $7^{\prime \prime}$ & 131.6 & $3^{\prime \prime}$ & 124.2 & 124.3 \\
$4^{\prime \prime}$ & 131.5 & $8^{\prime \prime}$ & 17.5 & $4^{\prime \prime}$ & 131.7 & 131.5 \\
$5^{\prime \prime}$ & 17.3 & $9^{\prime \prime}$ & 25.5 & $5^{\prime \prime}$ & 17.7 & 17.6 \\
\hline & 25.4 & $10^{\prime \prime}$ & 16.5 & $6^{\prime \prime}$ & 25.7 & 25.8 \\
\hline & 56.2 & $3-O C H_{3}$ & 56.1 & $3-O C H_{3}$ & 56.2 & 56.5 \\
\hline & 56.2 & $8-O C H_{3}$ & 56.1 & $8-O C H_{3}$ & 56.2 & 56.5 \\
\hline & & & & & &
\end{tabular}

The presence in the ${ }^{13} \mathrm{C}-\mathrm{NMR}$ data of 4 olefinic resonances for two trisubstituted double bonds clearly suggests a linear diprenyl chain in $\mathbf{2}, \mathbf{3}, \mathbf{6}, \mathbf{7}, \mathbf{1 0}$, and $\mathbf{1 7}$. The configurations at C-2' and C-3' for the linear diprenyl chain (as in $2,3,4,6,7,10,11$, and 17) can be established on the bases of the relatively low-field and high-field signals for the $\mathrm{C}-10^{\prime}$ of the $(Z)$ compound and the sterically more congested $(E)$ compound, respectively $[15,18]$. Thus, this $\delta$ value allows for the determination of whether the diprenylated substituent is a neryl or geranyl group. 
Table $7 .{ }^{13} \mathrm{C}$ chemical shifts ( $\delta$ in ppm) of conicaquinones, aplidinones, thiaplidiaquinones, and conithiaquinones.

\begin{tabular}{|c|c|c|c|c|c|c|c|c|c|c|c|c|}
\hline Carbon & 45 & 46 & Carbon & 47 & 48 & 49 & Carbon & 50 & 51 & Carbon & 52 & 53 \\
\hline Solvent & A & A & Solvent & $\mathrm{A}$ & A & $\mathrm{D}$ & Solvent & A & A & Solvent & $\mathrm{D}$ & $\mathrm{D}$ \\
\hline Ref. & [53] & [53] & Ref. & [54] & {$[54]$} & {$[54]$} & Ref. & [55] & {$[55]$} & Ref. & {$[58]$} & {$[58]$} \\
\hline 1 & 25.3 & 25.7 & 2 & 49.0 & 48.6 & 49.0 & 1 & 111.4 & 113.8 & 2 & 48.3 & 48.2 \\
\hline 2 & 135.6 & 133.3 & 3 & 40.5 & 40.1 & 41.0 & 2 & 149.7 & 148.9 & 3 & 39.4 & 39.3 \\
\hline 3 & 122.9 & 122.2 & $4 a$ & 144.3 & 149.5 & 151.0 & 3 & 120.0 & 133.4 & $4 a$ & 146.1 & 146.4 \\
\hline 4 & 28.7 & 29.3 & 5 & 179.3 & 173.1 & 174.5 & 4 & 132.3 & 118.4 & 5 & 181.5 & 181.5 \\
\hline 5 & 34.8 & 36.5 & 6 & 126.7 & 108.9 & 110.0 & $4 a$ & 145.9 & 148.1 & $5 \mathrm{a}$ & 148.0 & 150.0 \\
\hline 6 & 147.3 & 151.5 & 7 & 157.3 & 147.8 & 149.0 & 6 & 67.2 & 67.4 & 6 & 37.5 & 37.5 \\
\hline 7 & 135.5 & 133.2 & 8 & 174.2 & 175.4 & 176.6 & $6 a$ & 138.6 & 137.4 & $6 a$ & 47.5 & 48.1 \\
\hline 8 & 125.8 & 128.2 & $8 a$ & 109.2 & 109.2 & 109.0 & 7 & 175.1 & 175.2 & 7 & 21.1 & 21.7 \\
\hline 9 & 130.6 & 127.1 & $1^{\prime}$ & 22.2 & 23.4 & 24.0 & $7 \mathrm{a}$ & 110.1 & 109.9 & 8 & 33.1 & 33.7 \\
\hline 10 & 174.9 & 178.4 & $2^{\prime}$ & 119.2 & 119.5 & 124.8 & 9 & 48.6 & 48.6 & 9 & 82.7 & 82.4 \\
\hline 11 & 146.7 & 113.4 & $3^{\prime}$ & 137.6 & 138.4 & 137.0 & 10 & 39.9 & 39.8 & $9 a$ & 51.8 & 52.1 \\
\hline 12 & 113.4 & 146.7 & $4^{\prime}$ & 39.7 & 39.5 & 40.5 & $11 \mathrm{a}$ & 144.0 & 144.3 & 10 & 65.1 & 74.4 \\
\hline 13 & 178.9 & 174.8 & $5^{\prime}$ & 26.6 & 26.3 & 27.8 & 12 & 179.1 & 179.2 & $10 \mathrm{a}$ & 147.5 & 149.7 \\
\hline 14 & 129.3 & 132.6 & $6^{\prime}$ & 124.1 & 123.8 & 125.0 & $12 \mathrm{a}$ & 128.0 & 128.0 & 11 & 180.5 & 179.7 \\
\hline 15 & 126.0 & 126.5 & $7^{\prime}$ & 131.5 & 131.8 & 133.0 & $12 \mathrm{~b}$ & 116.6 & 114.4 & $11 \mathrm{a}$ & 110.0 & 110.3 \\
\hline 16 & 17.5 & 17.6 & $8^{\prime}$ & 25.6 & 25.7 & 26.1 & $1^{\prime}$ & 28.1 & 29.1 & $12-\mathrm{CH}_{3}$ & 21.2 & 21.6 \\
\hline 17 & 39.8 & 48.1 & $9^{\prime}$ & 16.1 & 16.2 & 16.5 & $2^{\prime}$ & 121.3 & 120.5 & $13-\mathrm{OCH}_{3}$ & 48.5 & 48.5 \\
\hline 18 & 48.2 & 39.8 & $10^{\prime}$ & 17.7 & 17.7 & 17.8 & $3^{\prime}$ & 136.8 & 138.7 & $16-\mathrm{OCH}_{3}$ & - & 58.0 \\
\hline- & - & - & $1^{\prime \prime}$ & - & - & 41.5 & $4^{\prime}$ & 39.7 & 39.8 & $14-\mathrm{CH}_{3}$ & 18.6 & 18.4 \\
\hline - & - & - & $2^{\prime \prime}$ & - & - & 51.5 & $5^{\prime}$ & 26.6 & 26.6 & $15-\mathrm{CH}_{3}$ & 25.4 & 25.7 \\
\hline- & - & - & $\mathrm{OCH}_{3}$ & 62.3 & - & - & $6^{\prime}$ & 124.1 & 123.9 & - & - & - \\
\hline- & - & - & - & - & - & - & $7^{\prime}$ & 131.4 & 131.8 & - & - & - \\
\hline- & - & - & - & - & - & - & $8^{\prime}$ & 25.7 & 25.7 & - & - & - \\
\hline- & - & - & - & - & - & - & $9^{\prime}$ & 16.1 & 16.2 & - & - & - \\
\hline- & - & - & - & - & - & - & $10^{\prime}$ & 16.1 & 17.7 & - & - & - \\
\hline- & - & - & - & - & - & - & $1^{\prime \prime}$ & 116.8 & 116.8 & - & - & - \\
\hline- & - & - & - & - & - & - & $2^{\prime \prime}$ & 145.3 & 145.0 & - & - & - \\
\hline- & - & - & - & - & - & - & $3^{\prime \prime}$ & 39.7 & 39.7 & - & - & - \\
\hline- & - & - & - & - & - & - & $4^{\prime \prime}$ & 26.2 & 26.2 & - & - & - \\
\hline- & - & - & - & - & - & - & $5^{\prime \prime}$ & 123.5 & 123.5 & - & - & - \\
\hline- & - & - & - & - & - & - & $6^{\prime \prime}$ & 131.7 & 131.8 & - & - & - \\
\hline- & - & - & - & - & - & - & $7^{\prime \prime}$ & 25.6 & 25.6 & - & - & - \\
\hline- & - & - & - & - & - & - & $8^{\prime \prime}$ & 17.3 & 17.4 & - & - & - \\
\hline- & - & - & - & - & - & - & $9^{\prime \prime}$ & 17.5 & 17.7 & - & - & - \\
\hline
\end{tabular}

The lack of ${ }^{13} \mathrm{C}$-NMR resonance for the group of unsaturated carbon atoms, which were substituted by a $\delta$-deshielded value $\left(\delta_{C} 70.9\right)$, as in 4 [15], suggest the presence of a hydroxyl group. This finding was also observed for compounds $\mathbf{1 1}$ and $\mathbf{1 2}$.

Conidinone (8), which has a cyclic diprenyl substituent, presented a 1H-NMR spectrum with signals at $\delta_{\mathrm{H}} 6.71(1 \mathrm{H}, \mathrm{d}, J=10.3 \mathrm{~Hz}), \delta_{\mathrm{H}} 6.87(1 \mathrm{H}, \mathrm{d}, J=10.3 \mathrm{~Hz}), \delta_{\mathrm{H}} 2.88(1 \mathrm{H}, \mathrm{d}, J=16.7 \mathrm{~Hz})$, and $\delta_{\mathrm{H}} 2.81(1 \mathrm{H}, \mathrm{d}, J=16.7 \mathrm{~Hz})$, defining the presence of a 2,2-disubstituted cyclohexenedione ring in the 
molecule. The ${ }^{13} \mathrm{C}$-NMR of $\mathbf{8}$ includes two $\alpha, \beta$-unsaturated ketone carbonyl signals, as well as a trisubstituted and a disubstituted double bond [21].

Compound 15 and 16 presented a substituted hydroquinone nucleus, together with a 3,4-disubstituted-1-methylcyclohexene ring, and 1-hydroxyisopropyl unit, which was attached to C-6' of the cyclohexene ring upon observation of the ROESY spectrum and NOE experiment, respectively. The difference between $\mathbf{1 5}$ and $\mathbf{1 6}$ was the presence of a methoxy group at $\mathbf{1 6}$ [31,35].

Compound 17 produced ${ }^{1} \mathrm{H}-\mathrm{NMR}$ spectrum resonances attributable to two aromatic protons at $\delta_{\mathrm{H}} 6.75(1 \mathrm{H}, \mathrm{d}, J=2.1 \mathrm{~Hz}, \mathrm{H}-5)$ and $\delta_{\mathrm{H}} 6.54(1 \mathrm{H}, \mathrm{d}, J=2.1 \mathrm{~Hz}, \mathrm{H}-3)$, two olefinic protons at $\delta_{\mathrm{H}} 5.29$ $\left(1 \mathrm{H}, \mathrm{t}, J=6.6 \mathrm{~Hz}, \mathrm{H}-2^{\prime}\right)$ and $\delta_{\mathrm{H}} 5.09\left(1 \mathrm{H}, \mathrm{t}, J=6.6 \mathrm{~Hz}, \mathrm{H}-6^{\prime}\right)$, three moderately deshielded methylene signals $\left(\delta_{\mathrm{H}} 3.27,2.08\right.$, and 2.00$)$, one methoxyl signal at $\delta_{\mathrm{H}} 3.83$, and three allylic methyl singlets at $\delta_{\mathrm{H}} 1.69, \delta_{\mathrm{H}} 1.65$, and $\delta_{\mathrm{H}} 1.58$. Direct comparison of the ${ }^{1} \mathrm{H}$ and ${ }^{13} \mathrm{C}$ chemical shifts of the aromatic ring signals of $\mathbf{1 7}$ with a synthetic derivative of $\mathbf{1 7}$ (compound which had a hydroxyl group at C-4 instead of the sulfate) allow Chan and co-worker to identified an upfield shift of C-4 and downfield shifts of C-3 and C-5 in the ${ }^{13} \mathrm{C}-\mathrm{NMR}$ spectrum and downfield shifts of $\mathrm{H}-3$ and $\mathrm{H}-5$ in the ${ }^{1} \mathrm{H}-\mathrm{NMR}$ spectrum which were consistent with the placement of the sulfate group at the C-4 [17].

The ${ }^{13} \mathrm{C}$-NMR data for Rossinone A (18), Table 3, allowed for the identifications of a triprenylated (farnesyl) hydroquinone-bearing substitution in the terminal prenyl unit. A $\alpha$-hydroxy ketone group $\left(\delta_{\mathrm{C}} 201.8\right)$ and a carbinol resonance at $\delta_{\mathrm{C}} 69.8$ in the side chain of 18 were established [23].

The Rossinone family, mainly compounds 19-22, have a cyclic triprenylated group. When comparing 19 and 20, the principal differences were in the chemical shift of the $\mathrm{AB}$ quartet due to the quinone protons resonating at higher fields $\left(\mathrm{H}-2: \delta_{\mathrm{H}} 3.75(\mathrm{~d}, J=3.5 \mathrm{~Hz})\right.$ in 19 and $\delta_{\mathrm{H}} 6.79(\mathrm{~d}$, $J=10.5 \mathrm{~Hz})$ in 20; H-3: $\delta_{\mathrm{H}} 3.80(\mathrm{~d}, J=3.5 \mathrm{~Hz})$ in 19 and $\delta_{\mathrm{H}} 6.90(\mathrm{~d}, J=10.5 \mathrm{~Hz})$ in 20). Additionally, the ${ }^{13} \mathrm{C}$-NMR spectrum of 19 contained signals at $\delta_{\mathrm{C}} 55.5(\mathrm{C}-2)$ and $\delta_{\mathrm{C}} 56.4(\mathrm{C}-3)$ in the place of the quinone resonances of 20 observed at $\delta_{\mathrm{C}} 139.0(\mathrm{C}-2)$ and $\delta_{\mathrm{C}} 141.2(\mathrm{C}-3)$ [38].

The compound 3-Epi-rossinone B (21) was an isomer of rossinone B (20). The analysis of the ${ }^{1} \mathrm{H}-\mathrm{NMR}$ revealed significant differences in the proton values of both $\mathrm{H}-7$ and $\mathrm{H}-11\left(\mathrm{H}-7: \delta_{\mathrm{H}} 2.06\right.$ in 20 and $\delta_{\mathrm{H}} 2.48$ in 21; H-11: $\delta_{\mathrm{H}} 2.67$ in 20 compared to $\delta_{\mathrm{H}} 2.10$ in 21) that could be explained by the diverse steric influence of the hydroxyl group in these two compounds; the structure was confirmed by NOE experiments [38].

For 5,6-Epoxy-rossinone B (22), revealed in ${ }^{1} \mathrm{H}-\mathrm{NMR}$ spectrum the lack of the double bond in ring B when compared with 20, which is substituted by an epoxide ring in 22. The H-6 was attributed to a singlet at $\delta_{\mathrm{H}} 3.80$. In the ${ }^{13} \mathrm{C}$-NMR spectrum the values at $\delta_{\mathrm{C}} 61.4$ and $\delta_{\mathrm{C}} 55.7$, were assigned to C- 6 and C-5, respectively. Additionally, due to the absence of the conjugated double bond, the C-4 quinone carbonyl in 22 was shifted down-field $\left(\delta_{\mathrm{C}} 193.9\right)$ with respect to $\mathbf{2 0}\left(\delta_{\mathrm{C}} 185.0\right)$ [38].

The complex and unprecedented structure of longithorone A (23) was determined by crystal X-ray diffraction, while the enantioselective biomimetic synthesis of longithorone A was accomplished by Layton and coworkers [59]. The ${ }^{1} \mathrm{H}$ and ${ }^{13} \mathrm{C}-\mathrm{NMR}$ of (23) (Table 4) revealed that 23 contained eight double bonds and five carbonyl groups, including one aldehyde $\left(\delta_{\mathrm{H}} 9.6\right.$ and $\left.\delta_{\mathrm{C}} 206.6\right)$, in accord with the presence of seven carbocycles to satisfy the unsaturation number revealed by the mass spectral data $\left(\mathrm{C}_{42} \mathrm{H}_{46} \mathrm{O}_{5}\right)[42]$.

Longithorones B (24) and C (25) are optically active isomers with the double bond configurations $2 E$ and $2 Z$ in 24 and 25, respectively. The singlets at $\delta_{\mathrm{H}} 6.23(\mathrm{H}-18)$ and $\delta_{\mathrm{H}} 6.45(\mathrm{H}-21)$ for 24 and 
$\delta_{\mathrm{H}} 6.38(\mathrm{H}-18$ and $\mathrm{H}-21)$ for 25 are representative of para-disubstituted benzoquinone core. The synthesis of Longithorone B was accomplished by Kato et al. [60].

The structures of longithorones E (27) and F (28) are very similar. However, the NOESY experiment for Longithorone F revealed that H-13 is spatially close to H-6, H-18, H-1 $\alpha$, and H-4a. On the other hand, the NOE experiment of 27 showed interactions between H-13 with H-6 and H-1 $\beta$, but not with H-18. Thus, the dimeric longithorones $\mathrm{E}(\mathbf{2 7})$ and $\mathrm{F}(\mathbf{2 8})$ are atropoisomers with respect to the para-disubstituted benzoquinone ring [40]. In turn, longithorone F (28) differs from longithorone $\mathrm{G}$ (29) in its C-2', C-3', and C-10' stereochemistry. The NOESY data for 29 revealed correlations between the aldehyde hydrogen $\mathrm{H}-13$ with $\mathrm{H}-5$ and $\mathrm{H}-2^{\prime}$ suggesting that these protons were all on the same face of the molecule. These correlations were not, however, observed in the NOE experiment for $\mathbf{2 8 .}$

The farnesyl chains in longithorone $\mathrm{J}(\mathbf{3 2})$ and $\mathrm{K}(\mathbf{3 3})$ were characterized by three shielded olefinic methyl resonances, two of these $\left(\delta_{\mathrm{C}} 14.9\right.$ and $\left.\delta_{\mathrm{C}} 16.9\right)$ assigned $E$-geometry configuration and the other $\left(\delta_{\mathrm{H}} 22.8\right)$ was assigned a Z-geometry. The ${ }^{1} \mathrm{H}$ and ${ }^{13} \mathrm{C}$-NMR spectra of longithorone $\mathrm{J}$ include an oxymethine proton at $\delta_{\mathrm{H}} 4.84\left(\delta_{\mathrm{C}} 71.5\right)$ in contrast to the presence of two ketone resonances at $\delta_{\mathrm{C}} 200.7$ and $\delta_{\mathrm{C}} 196.8$ in longithorone $\mathrm{K}(\mathbf{3 3})$. The absolute stereochemistry of longithorone $\mathrm{J}(\mathbf{3 2})$ has been determined by the advanced Mosher method, while the absolute stereochemistry for longithorone $\mathrm{K}$ (33) was suggested by comparison with 32 and based on biosynthesis [43].

A comparison of the ${ }^{1} \mathrm{H}$ and ${ }^{13} \mathrm{C}-\mathrm{NMR}$ data for longithorols $\mathrm{A}-\mathrm{D}$ (34-37) (Table 5) with previous longithorones reveals that, in longithorols, signals for two substituted 1,4-hydroquinones (C-16 to C-21 and $\mathrm{C}-16^{\prime}$ to $\mathrm{C}-21^{\prime}$ ) are present instead of signals for two substituted 1,4-quinones. In addition, an acetoxymethine group can be recognized by the signals at $\delta_{\mathrm{H}} 6.61\left(\mathrm{~d}, J=10.0 \mathrm{~Hz}\right.$ ) and $\delta_{\mathrm{C}} 67.1$ (for example, in 34), which replace the methylene group corresponding to $\mathrm{C}-1$ in longithorones [47]. The absolute stereochemistry of longithorol C (36) has been determined by the advanced Mosher method [48].

Floresolides skeleton can be recognized by the presence of an endocyclic $\varepsilon$-lactone with an $\alpha, \beta$-epoxy-group $\left(\delta_{\mathrm{C}} 63.7\right.$ and $\left.\delta_{\mathrm{C}} 59.1\right)$ in 38 and $\left(\delta_{\mathrm{C}} 62.5\right.$ and $\left.\delta_{\mathrm{C}} 58.3\right)$ in 39, and a double bond at the C-2 and C-3 position ( $\delta_{\mathrm{C}} 137.8$ and $\left.\delta_{\mathrm{C}} 136.1\right)$ in $\mathbf{4 0}$ (Table 5). The terminal methylene group at the $\mathrm{C}-11$ and $\mathrm{C}-12$ positions is also typical in this structural family. The Floresolide $\mathbf{3 9}$ has a primary alcohol and a fully substituted benzene ring including two bromine atoms in its structure. Compound 40 has absolute stereostructure, confirmed by crystal-X-ray diffraction [49].

Scabellones are conspicuous for the rare tricycle benzo[c] chromene-7,10 dione core in their structure. The signals at $\delta_{\mathrm{C}} 182.6(\mathrm{C}-1)$ and $\delta_{\mathrm{C}} 178.7(\mathrm{C}-4)$ (Table 6) define the presence of the quinonoid ring system, while the $\mathrm{HMBC}$ correlations from the aromatic proton resonance at $\delta_{\mathrm{H}} 6.40$ (H-7) to the ${ }^{13} \mathrm{C}$ resonances at $\delta_{\mathrm{C}} 150.0(\mathrm{C}-8), \delta_{\mathrm{C}} 139.2(\mathrm{C}-9), \delta_{\mathrm{C}} 151.4(\mathrm{C}-6 \mathrm{a})$ and $\delta_{\mathrm{C}} 111.0(\mathrm{C}-10 \mathrm{a})$, together with the methoxyl group at $\delta_{\mathrm{H}} 3.89(\mathrm{C}-8)$ and the signal at $\delta_{\mathrm{C}} 126.8$ (C-10), define the tetrasubstituted phenol in Scabellone B (42), the active representative compound of this family [17].

The structures of conicaquinones (45-46), aplidinones (47-49), thiaplidiaquinones (50-51) and conithiaquinones (52-53) have the presence of an unusual 1,1-dioxo-1,4-thiazine ring characterized by $\mathrm{N}-\mathrm{H}\left(\delta_{\mathrm{H}} 6.78\right)$, two methylene protons at $\delta_{\mathrm{H}} 4.10\left(\delta_{\mathrm{C}} 39.8\right)$ and $\delta_{\mathrm{H}} 3.36\left(\delta_{\mathrm{C}} 48.2\right)$ in common, as exemplified in Conicaquinone A (45) (Table 7) [53]. In turn, the aplidinones contain a geranyl chain that is attached to the system $-\mathrm{NHCH}_{2} \mathrm{CH}_{2} \mathrm{SO}_{2}{ }^{-}$in addition to the quinone ring. Finally, the thiaplidiaquinones and conithiquinones contain a tetracyclic skeleton. Thiaplidiaquinones have the same tricyclic 
6H-benzo[c] chromene-7,10-dione described for Scabellone B (42) in their structure [17]. On the other hand, the signals related to $\mathrm{C}-6$ to $\mathrm{C}-10$ in ${ }^{13} \mathrm{C}-\mathrm{NMR}$ spectra, in addition to the signal of the methoxyl group (C-13), the methyl protons C-12, C-14 and C-15 and the signal of hydroxy group positioned at $\mathrm{C}$-10 in the ${ }^{1} \mathrm{H}-\mathrm{NMR}$ spectra, establish the presence of $\mathrm{C}$ and $\mathrm{D}$ ring fused at 1,4-benzoquinone/ 1,1-dioxo-1,4-thiazide bicyclic system (A and B rings) of conithiaquinone skeleton [58].

\section{Conclusions}

The studies presented in this review reveal the importance of the prenylated quinone and hydroquinone metabolites, which have important biological activities and occur with frequency in ascidians of the genus Aplidium. Those non-nitrogenous metabolites, mainly prenyl quinones or hydroquinones, which can be either linear or cyclic compounds, such as rossinones, longithorones, longithorols, floresolides, scabellones, conicaquinols, aplidinones, thiaplidiaquinones, and conithiaquinones, are examples of meroterpenes. The evaluated compounds mainly presented cytotoxic, anti-inflammatory, and antimicrobial activities. Furthermore, ascidians (tunicates) are a promising source of new bioactive compounds from marine environments [61-63]. The Aplidium genus is able to produce meroterpenes with a large range of structural variety, of which the longithorone series is notable for containing the most complex structures with a metacyclophane and paracyclophane scaffolds. The complex and elaborate structure of some of these meroterpenoids has led several research groups to engage in performing the total synthesis of specific compounds for their structural confirmation and to clarify biosynthetic pathways. The ${ }^{13} \mathrm{C}$-NMR data of a given compound are an important tool for natural products research because it is sometimes possible to propose the structure of a novel natural compound by performing comparisons with data for known compounds. For example, the structure of rossinones, were deduced by comparing 2D NMR spectrum with those from literature data reported for rossinone B. Therefore, considering the enormous diversity in their chemical structures and the biological potential of the prenyl quinones and hydroquinones found in Aplidium, it is important to conduct further studies of this genus using a multidisciplinary approach.

\section{Acknowledgments}

CNPq (The National Council for Scientific and Technological Development) is acknowledged for Research Productivity Fellowships granted to M.L.A.S., W.R.C., A.H.J., and P.M.P. T.A.A. were supported by FAPESP (São Paulo Research Foundation) and C.S.B. by CAPES (Coordination for the Improvement of Higher Education Personnel) scholarships. FAPESP and CNPq/CAPES were also acknowledged for their financial support (grant \#2013/09280-6 and 23038.009588/2013-68).

\section{Author Contributions}

All the authors contributed to the writing of the manuscript. They jointly developed the structure and arguments for the paper. All the authors reviewed and approved the final manuscript.

\section{Conflicts of Interest}

The authors declare no conflict of interest. 


\section{References}

1. Rinehart, K.L. Antitumor Compounds from Tunicates. Med. Res. Rev. 2000, 20, 1-27.

2. Menna, M. Antitumor potential of natural products from Mediterranean ascidians. Phytochem. Rev. 2009, 8, 461-472.

3. Sunassee, S.N.; Davies-Coleman, M.T. Cytotoxic and antioxidant marine prenylated quinones and hydroquinones. Nat. Prod. Rep. 2012, 29, 513-535.

4. Lamarck, J.B. Histoire naturelle des animaux sans vertebres, Tome III. In Tuniciers; J.B. Baillière: Paris, France, 1816; pp. 1-586.

5. Lambert, C.C. Historical introduction, overview, and reproductive biology of the protochordates. Can. J. Zool. 2005, 83, 1-7.

6. Zeng, L.; Swalla, B.J. Molecular phylogeny of the protochordates: Chordate evolution. Can. J. Zool. 2005, 83, 24-33.

7. Monniot, C.; Monniot, F.; Laboute, P. Coral Reef Ascidians of New Caledonia; Orstom: Paris, France, 1991.

8. Cameron, C.B.; Garey, J.R.; Swalla, B.J. Evolution of the chordate body plan: New insights from phylogenetic analyses of deuterostome phyla. Proc. Natl. Acad. Sci. USA 2000, 97, 4469-4474.

9. Kott, P. New and little-known species of Didemnidae (Ascidiacea, Tunicata) from Australia (Part 3). J. Nat. Hist. 2005, 39, 2409-2497.

10. Shenkar, N.; Swalla, B.J. Global diversity of Ascidiacea. PLoS One 2011, 6, e20657.

11. Zubía, E.; Ortega, M.J.; Salvá, J. Natural Products Chemistry in Marine Ascidians of the Genus Aplidium. Mini Rev. Org. Chem. 2005, 2, 389-399.

12. Menna, M.; Imperatore, C.; D’Aniello, F.; Aiello, A. Meroterpenes from Marine Invertebrates: Structures, Occurrence, and Ecological Implications. Mar. Drugs 2013, 11, 1602-1643.

13. Dewick, P.M. Medicinal Natural Products: A Biosynthetic Approach, 3rd ed.; John Wiley \& Sons: Chichester, UK, 2009; pp. 178-184.

14. Howard, B.M.; Clarkson, K.; Bernstein, R.L. Simple prenylated hydroquinone derivatives from the marine Urochordate Aplidium californicum. Natural anticancer and antimutagenic agents. Tetrahedron Lett. 1979, 20, 4449-4452.

15. Guella, G.; Mancini, I.; Pietra, F. Verapliquinones-Novel diprenylquinones from an Aplidium sp. (Ascidiaceae) of Ile-Verters, Brittany. Helv. Chim. Acta 1987, 70, 621-626.

16. Davis, C.J.; Hurst, T.E.; Jacob, A.M.; Moody, C.J. Microwave-mediated Claisen rearrangement followed by phenol oxidation: A simple route to naturally occurring 1,4-benzoquinones. The first syntheses of verapliquinones A and B and panicein A. J. Org. Chem. 2005, 70, 4414-4422.

17. Chan, S.T.; Pearce, A.N.; Januario, A.H.; Page, M.J.; Kaiser, M.; McLaughlin, R.J.; Harper, J.L.; Webb, V.L.; Barker, D.; Copp, B.R. Anti-inflammatory and antimalarial meroterpenoids from the New Zealand ascidian Aplidium scabellum. J. Org. Chem. 2011, 76, 9151-9156.

18. Shubina, L.K.; Fedorov, S.N.; Radchenko, O.S.; Balaneva, N.N.; Kolesnikova, S.A.; Dmitrenok, P.S.; Bode, A.; Dong, Z.; Stonik, V.A. Desmethylubiquinone $\mathrm{Q}_{2}$ from the Far-Eastern ascidian Aplidium glabrum: Structure and synthesis. Tetrahedron Lett. 2005, 46, 559-562. 
19. Fedorov, S.N.; Radchenko, O.S.; Shubina, L.K.; Balaneva, N.N.; Bode, A.M.; Stonik, V.A.; Dong, Z. Evaluation of cancer-preventive activity and structure-activity relationships of 3-demethylubiquinone $\mathrm{Q}_{2}$, isolated from the ascidian Aplidium glabrum, and its synthetic analogs. Pharm. Res. 2006, 23, 70-81.

20. Fedorov, S.N.; Radchenko, O.S.; Shubina, L.K.; Balaneva, N.N.; Agafonova, I.G.; Bode, A.M.; Jin, J.O.; Kwak, J.Y.; Dong, Z.; Stonik, V.A. Anticancer activity of 3-demethylubiquinone $\mathrm{Q}_{2}$. In vivo experiments and probable mechanism of action. Anticancer Res. 2008, 28, 927-932.

21. Garrido, L.; Zubía, E.; Ortega, M.J.; Salvá, J. New meroterpenoids from the Ascidian Aplidium conicum. J. Nat. Prod. 2002, 65, 1328-1331.

22. Cotelle, N.; Moreau, S.; Cotelle, P.; Catteau, J.P.; Bernier, J.L.; Hénichart, J.P. Generation of free radicals by simple prenylated hydroquinone derivatives, natural antitumor agents from the marine Urochordate Aplidium californicum. Chem. Res. Toxicol. 1991, 4, 300-305.

23. Cotelle, N.; Moreau, S.; Bernier, J.L.; Catteau, J.P.; Hénichart, J.P. Antioxidant properties of natural hydroquinones from the marine colonial tunicate Aplidium californicum. Free Radic. Biol. Med. 1991, 11, 63-68.

24. Appleton, D.R.; Chuen, C.S.; Berridge, M.V.; Webb, V.L.; Copp, B.R. Rossinones A and B, biologically active meroterpenoids from the Antarctic ascidian, Aplidium species. J. Org. Chem. 2009, 74, 9195-9198.

25. Fenical, W. Geranyl hydroquinone, a cancer-protective agent from the tunicate Aplidium species. Food Drugs Sea Proc. 1976, 4, 388-394.

26. Rueda, A.; Zubía, E.; Ortega, M.J.; Salvá, J. A New Cytotoxic Prenylhydroquinone from a Mediterranean Tunicate of the Genus Aplydium. Nat. Prod. Lett. 1998, 11, 127-130.

27. Benslimane, A.F.; Pouchus, Y.F.; Le Boterff, J.; Verbist, J.F.; Roussakis, C.; Monniot, F. Substances Cytotoxiques et Antibacteriennes de l'Ascidie Aplidium antillense (in French). J. Nat. Prod. 1988, 51, 582-583.

28. Aiello, A.; Fattorusso, E.; Menna, M. Low Molecular Weight Metabolites of Three Species of Ascidians Collected in the Lagoon of Venice. Biochem. Syst. Ecol. 1996, 24, 521-529.

29. Aknin, M.; Dayan, T.L.; Rudi, A.; Kashman, Y.; Gaydou, E.M. Hydroquinone antioxidants from the Indian ocean tunicate Aplidium savignyi. J. Agric. Food Chem. 1999, 47, 4175-4177.

30. Manners, G.D.; Jurd, L. New natural products from marine borer resistant woods. A review. J. Agric. Food Chem. 1977, 25, 726-730.

31. Reynaulds, G.W.; Rodriguez, E. Geranyl hydroquinone: A contact allergen from trichomes of Phacelia crenulata. Phytochemistry 1979, 18, 1567-1568.

32. Manners, G.D. The hydroquinone terpenoids of Cordia elaeagnoides. J. Chem. Soc. Perkin Trans. I 1983, 1983, 39-43.

33. Fenical, W. In proceedings of the Food-Drugs From the Sea Conference, Marine Science Center, University of Puerto Rico, Mayaguez, Puerto Rico, 17-21 November 1974; Webber, H.H., Ruggieri, G.D., Eds.; Marine Technology Society: Washington, DC, USA, 1974; p. 388.

34. Sato, A.; Shindo, T.; Kasanuki, N.; Hasegawa, K. Antioxidant metabolites from the tunicate Amaroucium multiplicatum. J. Nat. Prod. 1989, 52, 975-981.

35. Simon-Levert, A.; Arrault, A.; Bontemps-Subielos, N.; Canal, C.; Banaigs, B. Meroterpenes from the ascidian Aplidium aff. densum. J. Nat. Prod. 2005, 68, 1412-1415. 
36. Simon-Levert, A.; Aze, A.; Bontemps-Subielos, N.; Banaigs, B.; Genevière, A.M. Antimitotic activity of methoxyconidiol, a meroterpene isolated from an ascidian. Chem. Biol. Interact. 2007, $168,106-116$.

37. Simon-Levert, A.; Menniti, C.; Soulère, L.; Genevière, A.M.; Barthomeuf, C.; Banaigs, B.; Witczak, A. Marine natural meroterpenes: Synthesis and antiproliferative activity. Mar. Drugs 2010, 8, 347-358.

38. Carbone, M.; Núñez-Pons, L.; Paone, M.; Castelluccio, F.; Avila, C.; Gavagnin, M. Rossinone-related meroterpenes from the Antarctic ascidian Aplidium fuegiense.

Tetrahedron 2012, 68, 3541-3544.

39. Núñez-Pons, L.; Carbone, M.; Vázquez, J.; Rodríguez, J.; Nieto, R.M.; Varela, M.M.; Gavagnin, M.; Avila, C. Natural products from Antarctic colonial ascidians of the genera Aplidium and Synoicum: Variability and defensive role. Mar. Drugs 2012, 10, 1741-1764.

40. Fu, X.; Hossain, B.; Shmitz, F.J.; van der Helm, D. Longithorones, unique prenylated para- and metacyclophane type quinones from the tunicate Aplidium longithorax. J. Org. Chem. 1997, 62, 3810-3819.

41. Davis, R.A.; Carroll, A.R.; Quinn, R.J. Longithorones J and K, two new cyclofarnesylated quinone derived metabolites from the australian ascidian Aplidium longithorax. J. Nat. Prod. 1999, 62, 158-160.

42. Fu, X.; Hossain, M.B.; Vanderhelm, D.; Schmitz, F.J. Longithorone-A-Unprecedented dimeric prenylated quinone from the tunicate Aplydium-Longithorax. J. Am. Chem. Soc. 1994, 116, 12125-12126.

43. Davis, R.A.; Carroll, A.R.; Watters, D.; Quinn, R.J. The absolute stereochemistry and cytotoxicity of the ascidian-derived metabolite, longithorone. J. Nat. Prod. Res. 2006, 14, 1277-1282.

44. Zakarian, J.E.; El-Azizi, Y.; Collins, S.K. Exploiting quadrupolar interactions in the synthesis of the macrocyclic portion of longithorone C. Org. Lett. 2008, 10, 2927-2930.

45. Huang, M.; Song, L.; Liu, B. Construction of the cyclophane core of the hirsutellones via a RCM strategy. Org. Lett. 2010, 12, 2504-2507.

46. Kotha, S.; Chava, A.S.; Shaikh, M. Diversity-oriented approach to macrocyclic cyclophane derivatives by Suzuki-Miyaura cross-coupling and olefin metathesis as key steps. J. Org. Chem. 2012, 77, 482-489.

47. Fu, X.; Ferreira, M.L.; Schmitz, F.J. Longithorols A and B, novel prenylated paracyclophane- and metacyclophane-type hydroquinones from the tunicate Aplidium longithorax. J. Nat. Prod. 1999, $62,1306-1310$.

48. Davis, R.A.; Carroll, A.R.; Quinn, R.J. Longithorols C-E. Three new macrocyclic sesquiterpene hydroquinone metabolites from the australian ascidian, Aplidium longithorax. J. Nat. Prod. 1999, 62, 1405-1409.

49. Issa, H.H.; Tanaka, J.; Rachmat, R.; Higa, T. Floresolides, new metacyclophane hydroquinone lactones from an ascidian, Aplidium sp. Tetrahedron Lett. 2003, 44, 1243-1245.

50. Briggs, T.F.; Dudley, G.B. Cyclization of polyenes. Synthesis of longithorone B, a sixteen-membered farnesylated p-benzoquinone. Synthesis of the floresolide B hydroquinone lactone core using ring-closing metathesis. Tetrahedron Lett. 2005, 46, 7793-7796. 
51. Nicolaou, K.C.; Xu, H. Total synthesis of floresolide $\mathrm{B}$ and $\Delta(6,7)$-Z-floresolide B. Chem. Commun. 2006, 14, 600-602.

52. Chen, Y.; Harmata, M. Benzothiazines in organic synthesis. An approach to floresolide B. Tetrahedron Lett. 2011, 52, 4069-4071.

53. Aiello, A.; Fattorusso, E.; Luciano, P.; Menna, M.; Esposito, G.; Iuvone, T.; Pala, D. Conicaquinones A and B, Two Novel Cytotoxic Terpene Quinones from the Mediterranean Ascidian Aplidium conicum. Eur. J. Org. Chem. 2003, 2003, 898-900.

54. Aiello, A.; Fattorusso, E.; Luciano, P.; Mangoni, A.; Menna, M. Isolation and Structure Determination of Aplidinones A-C from the Mediterranean Ascidian Aplidium conicum: A Successful Regiochemistry Assignment by Quantum Mechanical ${ }^{13} \mathrm{C}-\mathrm{NMR}$ Chemical Shift Calculations. Eur. J. Org. Chem. 2005, 2005, 5024-5030.

55. Aiello, A.; Fattorusso, E.; Luciano, P.; Macho, A.; Menna, M.; Muñoz, E. Antitumor effects of two novel naturally occurring terpene quinones isolated from the Mediterranean ascidian Aplidium conicum. J. Med. Chem. 2005, 48, 3410-3416.

56. Carbone, A.; Lucas, C.L.; Moody, C.J. Biomimetic synthesis of the apoptosis-inducing thiazinoquinone thiaplidiaquinone A. J. Org. Chem. 2012, 77, 9179-9189.

57. Khalil, I.M.; Barker, D.; Copp, B.R. Biomimetic synthesis of thiaplidiaquinones A and B. J. Nat. Prod. 2012, 75, 2256-2260.

58. Menna, M.; Aiello, A.; D’Aniello, F.; Imperatore, C.; Luciano, P.; Vitalone, R.; Irace, C.; Santamaria, R. Conithiaquinones A and B, Tetracyclic Cytotoxic Meroterpenes from the Mediterranean Ascidian Aplidium conicum. Eur. J. Org. Chem. 2013, 2013, 3241-3246.

59. Layton, M.E.; Morales, C.A.; Shair, M.D. Biomimetic synthesis of (-)-longithorone A. J. Am. Chem. Soc. 2002, 124, 773-775.

60. Kato, T.; Nagae, K.; Hoshikawa, M. Synthesis of longithorone B, a sixteen-membered farnesylated $p$-benzoquinone. Tetrahedron Lett. 1999, 40, 1941-1944.

61. Blunt, J.W.; Copp, B.R.; Keyzers, R.A.; Munro, M.H.G.; Prinsep, M.R. Marine natural products. Nat. Prod. Rep. 2014, 31, 160-258.

62. Blunt, J.W.; Copp, B.R.; Keyzers, R.A.; Munro, M.H.G.; Prinsep, M.R. Marine natural products. Nat. Prod. Rep. 2013, 30, 237-323.

63. Gerwick, W.H.; Moore, B.S. Lessons from the Past and Charting the Future of Marine Natural Products Drug Discovery and Chemical Biology. Chem. Biol. 2012, 19, 1631.

(C) 2014 by the authors; licensee MDPI, Basel, Switzerland. This article is an open access article distributed under the terms and conditions of the Creative Commons Attribution license (http://creativecommons.org/licenses/by/3.0/). 